\title{
Immune recognition of salivary proteins from the cattle tick Rhipicephalus microplus differs according to the genotype of the bovine host
}

Gustavo Rocha Garcia', Sandra Regina Maruyama', Kristina T. Nelson², José Marcos Chaves Ribeiro³, Luiz Gustavo Gardinassi ${ }^{1}$, Antonio Augusto Mendes Maia ${ }^{4}$, Beatriz Rossetti Ferreira ${ }^{1,5}$, Frans N. J. Kooyman ${ }^{6}$ and Isabel K. F. de Miranda Santos ${ }^{1 *}$

\begin{abstract}
Background: Males of the cattle tick Rhipicephalus microplus produce salivary immunoglobulin-binding proteins and allotypic variations in $\mathrm{lgG}$ are associated with tick loads in bovines. These findings indicate that antibody responses may be essential to control tick infestations. Infestation loads with cattle ticks are heritable: some breeds carry high loads of reproductively successful ticks, in others, few ticks feed and they reproduce inefficiently. Different patterns of humoral immunity against tick salivary proteins may explain these phenotypes.

Methods: We describe the profiles of humoral responses against tick salivary proteins elicited during repeated artificial infestations of bovines of a tick-resistant (Nelore) and a tick-susceptible (Holstein) breed. We measured serum levels of total lgG1, IgG2 and IgE immunoglobulins and of lgG1 and IgG2 antibodies specific for tick salivary proteins. With liquid chromatography followed by mass spectrometry we identified tick salivary proteins that were differentially recognized by serum antibodies from tick-resistant and tick-susceptible bovines in immunoblots of tick salivary proteins separated by two-dimensional electrophoresis.

Results: Baseline levels of total IgG1 and IgG2 were significantly higher in tick-susceptible Holsteins compared with resistant Nelores. Significant increases in levels of total lgG1, but not of lgG2 accompanied successive infestations in both breeds. Resistant Nelores presented with significantly higher levels of salivary-specific antibodies before and at the first challenge with tick larvae; however, by the third challenge, tick-susceptible Holsteins presented with significantly higher levels of IgG1 and lgG2 tick salivary protein-specific antibodies. Importantly, sera from tick-resistant Nelores reacted with 39 tick salivary proteins in immunoblots of salivary proteins separated in two dimensions by electrophoresis versus only 21 spots reacting with sera from tick-susceptible Holsteins.

Conclusions: Levels of tick saliva-specific antibodies were not directly correlated with infestation phenotypes. However, in spite of receiving apparently lower amounts of tick saliva, tick-resistant bovines recognized more tick salivary proteins. These reactive salivary proteins are putatively involved in several functions of parasitism and blood-feeding. Our results indicate that neutralization by host antibodies of tick salivary proteins involved in parasitism is essential to control tick infestations.
\end{abstract}

Keywords: Immunoglobulins, Proteome, Immunoproteome, Antibody response, Rhipicephalus microplus, Tick saliva, Bos taurus, Bos indicus

\footnotetext{
* Correspondence: imsantos@fmrp.usp.br

${ }^{1}$ Department of Biochemistry and Immunology, Ribeirão Preto School of

Medicine, University of São Paulo, Ribeirão Preto, São Paulo, Brazil

Full list of author information is available at the end of the article
} 


\section{Background}

Rhipicephalus microplus, the cattle tick, threatens animal health and cattle production worldwide [1]. The direct and indirect effects of infestations by $R$. microplus cause losses in the order of billions of dollars annually $[2,3]$. In Brazil, home to the largest commercial herd of cattle, the losses exceed 3.24 billion dollars a year [4]. Despite these losses, a reliable and sustainable method of tick control is not available. The available anti-tick vaccines offer partial and transient protection and the chemical agents result in environmental contamination, residues in food products and promote acaricideresistant ticks $[5,6]$.

Bovine hosts present contrasting and heritable phenotypes for tick infestations [7, 8]. Breeds of Bos indicus (indicine) cattle are more resistant to $R$. microplus than those of B. taurus (taurine) cattle, possibly because the former were domesticated in Asia [9, 10], which is also believed to be the place of origin of the parasite [11]. Even after they undergo repeated infestations, taurine breeds still remain susceptible to levels of tick loads that are unacceptable in terms of animal productivity and health [7, 8, 12-16]. Knowledge about the mechanisms involved in the hosts' resistance to ticks will point to the path of new strategies of tick control.

Tick saliva is responsible for the success of parasite attachment, blood-feeding and transmission of pathogens to hosts $[17,18]$. It is a complex xenobiotic substance that is composed of soluble proteins presenting an array of different functions. In the model for studying tick-host interactions employed in the present study, saliva is constantly inoculated into the host for three weeks and, by accounting for the saliva produced by each tick throughout the infestation [19], highly infested hosts can receive approximately $200 \mathrm{ml}$ of saliva and protein to the level of milligrams. Given the importance of antibodies in neutralizing venoms and salivary mediators of parasitism, we and others [20-22] have made several observations on antibody responses made by bovine hosts against tick antigens. While hosts indeed produce antibodies against tick salivary proteins, a tenet of immunology is that soluble antigens administered in large quantities without aggregation or adjuvants are not immunogenic [23, 24], which is the case at the host-tick interface. Therefore, neutralization of tick salivary mediators of parasitism by host antibodies might be compromised in tick-susceptible taurine hosts.

We have previously described the antibody responses to tick saliva in bovine hosts that were managed in pastures naturally infested with high or low numbers of ticks [25]. We reported that, in spite of less ticks feeding on tick-resistant bovines (Nelore breed, $B$. indicus), these hosts presented with significantly higher levels of tick saliva-specific IgG1 and IgG2 antibodies than tick- susceptible bovines (Holstein breed, B. taurus) when the latter hosts are presenting with heavy tick loads. Furthermore, in another tick-susceptible breed (Aberdeen) only levels of IgG1, but not IgG2 saliva-specific antibodies were positively correlated with tick loads acquired in naturally infested pastures. Cruz and colleagues [26] obtained similar results when they examined total IgG saliva-specific antibody responses after artificial infestations in the tick-susceptible Hereford breed. A study by Piper and colleagues [27] examined differences in antibody responses mounted by tick-resistant Brahmans and tick-susceptible Holsteins artificially infested with ticks and found that IgG1, but not IgG2 tick-specific antibodies were significantly higher in susceptible hosts than in resistant hosts.

Clearly more information is needed about the development of the antibody response to tick saliva. The present study sought to generate more information on antibody responses to ticks. For this, we examined the antibody responses to different sets of tick salivary antigens in the model of contrasting phenotypes of infestations between tick-resistant (Nelore breed, $B$. indicus) and ticksusceptible (Holstein breed, B. taurus) bovines undergoing artificial infestations with larvae of $R$. microplus ticks. Serum samples were collected in hosts kept free of ticks until the first infestation and during sequential stages of the parasite's life-cycle for three successive infestations. Levels of total IgG1, IgG2, IgE and of IgG1 and IgG2 antibodies specific for saliva and for extracts of female salivary glands (FSG) were measured through enzyme-linked immunosorbent assays (ELISA). In addition, the recognition of antigens from female tick saliva and extracts of unfed larvae (UFL), of male salivary glands (MSG) and of FSG by bovine IgG antibodies was evaluated by immunoblotting tick proteins separated in one dimension; the identity of reactive antigens from female tick saliva was evaluated by immunoblotting tick proteins separated in two dimensions followed by spot picking and sequencing proteins of gels prepared in parallel. We show that bovines presenting contrasting tick loads, i.e. animals of Nelore and Holstein breeds, present significant differences in their levels of total IgG1, IgG2 and IgE and in their antibody responses against tick antigens along successive infestations. Furthermore, in spite of a much lower exposure to tick antigens, resistant Nelore hosts recognize a larger set of tick salivary antigens.

\section{Methods}

Hosts, phenotypes of infestations and experimental design for collection of sera

Animals entered the experiment at six months of age before contact with $R$. microplus ticks. These were nonrelated, six-months old calves, four of the Nelore breed 
(genetically tick-resistant, Bos taurus indicus), and four of the Holstein breed (genetically tick-susceptible, Bos taurus taurus). They were kept stabled at the University of São Paulo's farm, located in Pirassununga, São Paulo State, Brazil. The calves were maintained free of ticks from birth with the following measures: the pregnant mothers were strategically treated with acaricides and maintained in a clean pasture, the newborn calves were housed in sand hutches during the weaning period and were submitted to strategic acaricide treatments. At the beginning of the experiment sera were collected from calves after which they were infested artificially with approximately 10,000 15-day-old unfed larvae of $R$. microplus from our colony $[28,29]$ maintained on Holstein oxen and originated from ticks collected at the University farm at Pirassununga. The phenotypes for resistance and susceptibility to ticks of the two breeds were confirmed by counting female ticks larger than $4 \mathrm{~mm}$ on the left side of each animal on the 21st day after release of larvae for the first infestation and these results and the procedure performed with the experimental animals used in the present study has been previously described [30].

For studies of antibody responses against saliva and FSG, sera were collected from calves before contact with ticks and when they were infested with ticks at the following stages of their life-cycle: two days after larvae were released and 7 and 15 days after infestation, when larvae had molted to nymphs and adults, respectively; three successive infestations were made with an interval of two months between the first and second and an interval of three months between the second and third; seven months lapsed between the beginning of the first infestation and the end of the last. Serum samples were obtained from peripheral blood collected in Vaccutainer tubes without anticoagulants followed by centrifugation and inactivation at $56{ }^{\circ} \mathrm{C}$ for $30 \mathrm{~min}$. All samples were aliquoted and stored at $-20{ }^{\circ} \mathrm{C}$ until use. Characteristics of sera evaluated in this study are described in Additional file 1: Table S1.

\section{Ticks}

In order to obtain saliva, 400 semi-engorged female ticks were taken directly from susceptible hosts (Holstein breed), washed, dried and injected in the haemocoele with a solution of dopamine (Revivan', Zambon, São Paulo, Brazil). Saliva was collected in protease inhibitors according to manufacturer's recommendations (Complete, Mini EDTA-free, Roche, Basel, Switzerland) and frozen at $-20{ }^{\circ} \mathrm{C}$. FSG and MSG were collected from ticks fed on susceptible (hereafter designated FSGS or MSGS) and resistant hosts (FSGR or MSGR) under a dissecting microscope and with sterile dissection tools and the glands were put in water with protease inhibitors. The samples were sonicated in order to obtain the extract. The extracts of
UFL were obtained from $1 \mathrm{mg}$ of egg masses from female ticks fed on resistant or susceptible hosts (hereafter designated UFLS and UFLR). The larvae were put in water with protease inhibitors according to the manufacturer's recommendations (Complete, Mini EDTA-free, Roche, Basel, Switzerland), followed by pulverization using a pestle and liquid nitrogen in order to obtain the extract. Proteins concentrations were measured by the Coomassie assay, according to the manufacturer's instructions (Pierce, Rockford, IL, USA).

\section{Measurement of total $\lg \mathrm{G} 1, \lg \mathrm{G} 2$ and $\lg E$ and detection and measurement of tick anti-salivary protein $\lg G 1$ and IgG2 antibodies \\ Enzyme-linked immunosorbent assays (ELISA)}

Levels of total IgG1 and IgG2 from cattle were measured in sera described in Additional file 1: Table S1 using a Bovine IgG1 and IgG2 ELISA quantification Kit (Bethyl Labs, Montgomery, TX, USA) according to the manufacturer's instructions. The measurement of levels of total IgE was performed according to the ELISA protocol developed by Kooyman and colleagues [31]. Briefly, monoclonal anti-sheep IgE diluted to 1:100 was used as capture antibody and test sera were diluted 1:5 and incubated on the plates, followed by incubation with a second, polyclonal rabbit anti-bovine IgE antibody solution diluted 1:250. Afterwards, goat anti-rabbit IgG antibody conjugated with alkaline phosphatase (Dako, Glostrup, Denmark) was used at a 1:1000 dilution and a color was developed with p-nitrophenyl phosphatase chromogenic solution (Sigma Chemical Company, St. Louis, USA) after incubation during $30 \mathrm{~min}$ at room temperature and overnight at $4{ }^{\circ} \mathrm{C}$. The measurement of levels of saliva and FSG extract-specific IgG1 and IgG2 antibodies were performed according to the ELISA protocol developed by Kashino et al. [25]. Results are expressed as the values of absorbance at $450 \mathrm{~nm}$ minus the absorbance of duplicate blank samples included in each plate. The endpoint titers displayed were determined to be the last of serial twofold dilutions presenting a significant difference in the optical density at $450 \mathrm{~nm}$ when compared to that seen in the corresponding dilution of sera from a different experimental group.

\section{Immunoblotting of tick antigens}

Immunoblotting of tick salivary proteins separated in one dimension FSG extracts $(14 \mu \mathrm{g})$, MSG extracts $(8 \mu \mathrm{g})$ and UFL extracts $(24 \mu \mathrm{g})$ were separated using $12.5 \%$ SDS polyacrylamide gels on a vertical unit (BioRad, Hercules, California, USA), with the initial amperage at $15 \mathrm{~mA} /$ gel for $15 \mathrm{~min}$ followed by $30 \mathrm{~mA} / \mathrm{gel}$ to total separation. After resolving in one dimension, the extracts were transferred from polycrylamide gels to Hybond ECL nitrocellulose sheets (GE Healthcare 
BioSciences Corporation, Piscataway, USA) using TE 70 semi-dry transfer unit (GE Healthcare BioSciences Corporation, Piscataway, USA) and pre-stained protein standards (BioRad, Hercules, California, USA) were used to monitor blot transfer. These membranes were incubated with pooled sera using dilutions at $1: 75$ for $4 \mathrm{~h}$ at $37{ }^{\circ} \mathrm{C}$. After washing, the membranes received the peroxidase conjugated Protein G (Thermo Scientific Pierce, Waltham, Massachusetts, USA) diluted at 1:2500 and ECL Western Blotting Substrate (Thermo Scientific Pierce, Waltham, Massachusetts, USA) to detect the antigens reactive with sera from different timepoints through chemiluminescence in an ImageQuant 350 detection system (GE Healthcare BioSciences Corporation, Piscataway, USA). Proteins in samples similar to those described above were separated under the same conditions and stained using a kit of PlusOne Coomassie Tablets (GE Healthcare BioSciences Corporation, Piscataway, USA) in order to verify their protein profiles.

Immunoblotting of tick salivary proteins separated in two dimensions and Spot Picking The twodimensional electrophoreses were made in $13 \mathrm{~cm}$ strips of immobilized gradient (IPG) at $\mathrm{pH}$ 3-10NL (GE Healthcare BioSciences Corporation, Piscataway, USA). The amount of protein sample used per strip was $200 \mu \mathrm{g}$ (except to gel used for spot picking that was $400 \mu \mathrm{g}$ ) and six gels were run in parallel for spot picking for identification of proteins and for immunoblotting to identify the salivary components that react with sera from ticknaïve and tick infested susceptible and resistant hosts. The saliva was treated with $100 \%$ trichloroacetic acid to eliminate residual dopamine at a final concentration of $10 \%$ for $1 \mathrm{~h}$ at $4{ }^{\circ} \mathrm{C}$. The proteins were then centrifuged at $14,000 \mathrm{rpm}$ at $4{ }^{\circ} \mathrm{C}$ for $15 \mathrm{~min}$, the supernatant discarded and the pellet was washed three times with acetone $(500 \mu \mathrm{l}$ of acetone for each $1 \mathrm{ml}$ of saliva) and centrifuged at $10,000 \mathrm{rpm}$ for $10 \mathrm{~min}$. After washing with acetone, the pellet was re-suspended in rehydration solution (7 M of urea, $2 \mathrm{M}$ tiourea, 4\% CHAPS, $20 \mathrm{mM}$ DTT). The strips were rehydrated for 10-14 h. Thereafter, electrophoresis in strips was performed on an IPGPhor equipment (GE Healthcare Bio-sciences Corp, Piscataway, USA) according to the manufacturer's recommendations for IPG strips of $13 \mathrm{~cm}$ (i.e. 1 step at $500 \mathrm{~V}$ during $1 \mathrm{~h}$, followed by gradient of $1,000 \mathrm{~V}$ and $8,000 \mathrm{~V}$ for $1 \mathrm{~h}$ and $2 \mathrm{~h} 30$ min, respectively; and a finishing step of $8,000 \mathrm{~V}$ during $1 \mathrm{~h}$, totaling $5 \mathrm{~h} 30 \mathrm{~min}$ or until $16-20 \mathrm{kVh}$ are accumulated). The strips were balanced in a solution containing SDS and urea $(50 \mathrm{mM}$ Tris, $6 \mathrm{M}$ urea, $2 \%$ SDS, $30 \%$ glycerol, $\mathrm{pH} 8.8$ ) and DTT $(100 \mathrm{mg} / 10 \mathrm{ml})$ for $15 \mathrm{~min}$ under mild shaking, and then iodacetamide $(250 \mathrm{mg} / 10 \mathrm{ml})$ for another $15 \mathrm{~min}$ under mild shaking. The second dimension of resolution was run in $12.5 \%$ SDS polyacrylamide gels on a SE600 (GE Healthcare Bio-sciences Corp, Piscataway, USA), with the initial amperage at $15 \mathrm{~mA} /$ gel for $15 \mathrm{~min}$ followed by $30 \mathrm{~mA} /$ gel until total separation. After running, the 2D gels were stained with silver nitrate or electrotransferred onto PVDF membrane at $10 \mathrm{~V}, 400 \mathrm{~mA}$ for $25 \mathrm{~min}$ in transfer buffer ( $48 \mathrm{mM}$ Tris, $39 \mathrm{mM}$ Glycine, $20 \%$ methanol and $0.375 \%$ SDS) using ECL semi-dry transfer unit (GE Healthcare BioSciences Corporation, Piscataway, USA). The membranes were blocked for $14 \mathrm{~h}$ with $5 \%$ skimmed milk diluted in TBS-T $(50 \mathrm{mM}$ Tris, $0.1 \mathrm{M}$ $\mathrm{NaCl}, 0.05 \%$ Tween, $\mathrm{pH}$ 7.2). They were then washed twice for $5 \mathrm{~min}$ with TBS-T and then incubated with pooled sera diluted 1:100 in TBS-T 0.01\% Azide and 2.5\% bovine serum albumin with shaking for $14 \mathrm{~h}$ at $4{ }^{\circ} \mathrm{C}$ followed by washing 3 times for 5 min with TBS-T. To verify the antibody-antigen reaction $\mathrm{G}$ protein conjugated with peroxidase (Invitrogen Corporation, Carlsbad, CA) was employed diluted 1:2000 and incubated with the membranes under agitation for 1 hat $37^{\circ} \mathrm{C}$, followed by 3 washes for $5 \mathrm{~min}$ with TBS-T and incubation with ECL Western Blotting Substrate (Thermo Scientific Pierce, Waltham, Massachusetts, USA) and the visualization of the spots was shown using the Multifunctional Imaging System (GE Healthcare Bio-sciences Corp, Piscataway, USA). The gel model was used to collect the spots of interest based on the results of western blots. The spots were collected using individual sterile pipette tips into tubes containing sterile water and stored until sequencing.

\section{Sequencing of tick salivary proteins by liquid chromatography and mass spectrometry (LC-MS)}

The spots previously selected and collected were transferred to a new tube, washed and destained with $500 \mu \mathrm{l}$ of a $50 \%$ methanol solution for $14 \mathrm{~h}$. The spots were dehydrated in $200 \mu \mathrm{l}$ of acetonitrile and rehydrated in $30 \mu \mathrm{l}$ of $10 \mathrm{mM}$ DTT in $0.1 \mathrm{M}$ ammonium bicarbonate and reduced for $30 \mathrm{~min}$ at RT. The DTT solution was removed and the samples were alkylated in $30 \mu \mathrm{l}$ of $50 \mathrm{mM}$ iodoacetamide in $0.1 \mathrm{M}$ ammonium bicarbonate at RT for $30 \mathrm{~min}$. The solution was removed and the spots were dehydrated in $100 \mu \mathrm{l}$ of acetonitrile. Acetonitrile was removed and the spots were rehydrated in $100 \mu \mathrm{l}$ of $0.1 \mathrm{M}$ ammonium bicarbonate. Subsequently, the spots were dehydrated again in $100 \mu \mathrm{l}$ of acetonitrile and this solution was then removed and the spots were completely dried by vacuum centrifugation. Spots were then rehydrated in $20 \mathrm{ng} / \mu \mathrm{l}$ of trypsin in $50 \mathrm{mM}$ ammonium bicarbonate for $10 \mathrm{~min}$ on ice, followed by digestion $14 \mathrm{~h}$ at $37{ }^{\circ} \mathrm{C}$. Afterwards, any excess trypsin solution was removed by pipetting and $20 \mu \mathrm{l}$ of $50 \mathrm{mM}$ ammonium bicarbonate were added. The peptide fragments were placed in two $30 \mu$ l aliquots of $50 \%$ 
acetonitrile in 5\% formic acid. These extracts were combined and evaporated for sequencing with mass analysis.

For LC-MS, we employed a hybrid LTQ-Orbitrap mass spectrometer Thermo Electron system with an ion source "nanospray" connected to a reverse phase capillary column C18 Waters NanoAcquity (Thermo Scientific Pierce, Waltham, Massachusetts, USA). Approximately $2-5 \mu \mathrm{g}$ of peptides were injected into these columns. Peptides that were not attached to the SCX column $(\mathrm{C} 18)$ were then eluted by an acetonitrile gradient in $0.1 \mathrm{M}$ formic acid with a flow rate of $0.4 \mu \mathrm{l} / \mathrm{min}$ for $1 \mathrm{~h}$. After this continuous flow fractionation, eight fractions of ion exchange were eluted on a C18 column, using aliquots of increasing concentration of ammonium acetate. Each fraction was analyzed by an acetonitrile gradient in $0.1 \mathrm{M}$ formic acid with a flow rate of $0.4 \mu \mathrm{l} / \mathrm{min}$. for $1 \mathrm{~h}$. The source of nanospray ion was operated at $3.5 \mathrm{kV}$.

The output data from each sample were analyzed in search database using Sequest search algorithm. Our sialotranscriptome of $R$. microplus served as a database for these searches (BioProject ID PRJNA329522). The peptides and proteins identified in the samples were inputed into Scaffold format file. The reliability of peptides identification was evaluated using the following criteria analysis in Scaffold software: (i) minimum of two unique peptides for each protein identified; (ii) 99\% minimum probability of protein identification; and (iii) $95 \%$ minimum probability peptide identification. The bioproject that contained the sequences obtained from sialotranscriptome of $R$. microplus informed above served as tick database for identification of peptides isolated from immunoproteomes and is deposited at GenBank (NCBI): Rhipicephalus microplus: BioProject ID 329522.

\section{Statistical analysis}

Statistical analyses were performed using the Student's $t$ test and the one-way analysis of variance (ANOVA) to evaluate significance among groups and the influence of two different variables on one continuous variable, respectively. $P$-value $<0.05$ was used to establish the level of significance. Tukey's multiple comparisons test (posthoc analysis) was used to find means that are significantly different from each other. GraphPad Prism 6 version 6.01 (San Diego, CA, USA) was used to perform the statistical tests.

\section{Results}

The cattle tick $R$. microplus is a one host (monoxene) tick and spends the entire parasitic stage of its life-cycle, approximately three weeks, on the same host. This period is sufficient for the host to mount primary and secondary antibody responses against those tick salivary components that are produced at the beginning or over the entire parasitic stage. Highly infested hosts receive large amounts of tick saliva, which contains many immunosupressants, including immunoglobulin-binding proteins, which are abundantly transcribed in salivary glands of the feeding male tick [32], coinciding with the appearance of the host's acquired immune response. The genetic composition of hosts affects the nature of the antibody response, including levels of total immunoglobulins [33-37], the IgG subclasses recruited, and antibody specificities [33, 38]. On the other hand, ticks ingest large amounts of host immunoglobulins presenting antibody activity [39]. In view of these data we examined several aspects of the humoral response in bovines of an indicine and of a taurine breed known to be genetically resistant or susceptible, respectively, to the cattle tick, $R$. microplus. Ticks loads in the Nelore and Holstein hosts examined in the present study were assessed as previously described [30], confirming the significant differences between these breeds.

\section{The effect of breed and of tick infestations on levels of total IgG1, IgG2 and IgE immunoglobulins in different breeds of bovines}

We first measured the serum immunoglobulins from both breeds before they were exposed to $R$. microplus. The results of ELISA show that the baseline levels (i.e. before infestations) of total IgG1 and IgG2 differ significantly between resistant and susceptible hosts $\left(t_{(4.878)}=6, P=0.0028\right.$ and $t_{(13.43)}=6, P<0.0001$, respectively; Fig. 1a, b). Regarding levels of total IgE (Fig. 1c), no differences were seen between the two breeds.

We then examined levels of total IgG1, IgG2 and IgE in the same hosts during three successive artificial infestations with 10,000 tick larvae at the time points corresponding to the three developmental stages of the tick: larvae, nymph or adult. During the first infestation, levels of total IgG1 decreased significantly (ANOVA, $F_{(1.482,}$ $4.447)=6.386, P=0.0533$ ) in tick-susceptible Holsteins relative to baseline levels during all developmental stages of the tick (i.e. larvae, nymphs and adults; Fig. 1a) and similar differences were observed for total IgG2, but were not significant (Fig. 1b); relative to baseline levels, the levels of total IgG1 and IgG2 (Fig. 1a, b, respectively) did not change significantly in tick-resistant Nelore hosts.

During the second and third infestations the levels of total IgG1 increased in both breeds, but were significantly higher in Holsteins when compared with Nelores $\left(t\right.$-test, $t_{(3.867)}=6, P=0.0083$ and $t_{(5.613)}=5, P=0.0025$, respectively; Fig. 1a). The levels of total IgG2 were, in general, significantly (first infestation: $t$-test, $t_{(6.631)}=6$, $P=0.0006$ (larval stage); second infestation: $t$-test, $t_{(8.785)}$ $=6, P=0.0001, t_{(5.709)}=6, P=0.0013$ and $t_{(5.695)}=6, P=$ 0.0013 ; third infestation: $t$-test, $t_{(2.999)}=5, P=0.0301$, $t_{(5.018)}=5, P=0.0040$ and $t_{(5.819)}=5, P=0.0021$; larval, nymphal and adult stages, respectively) higher in 


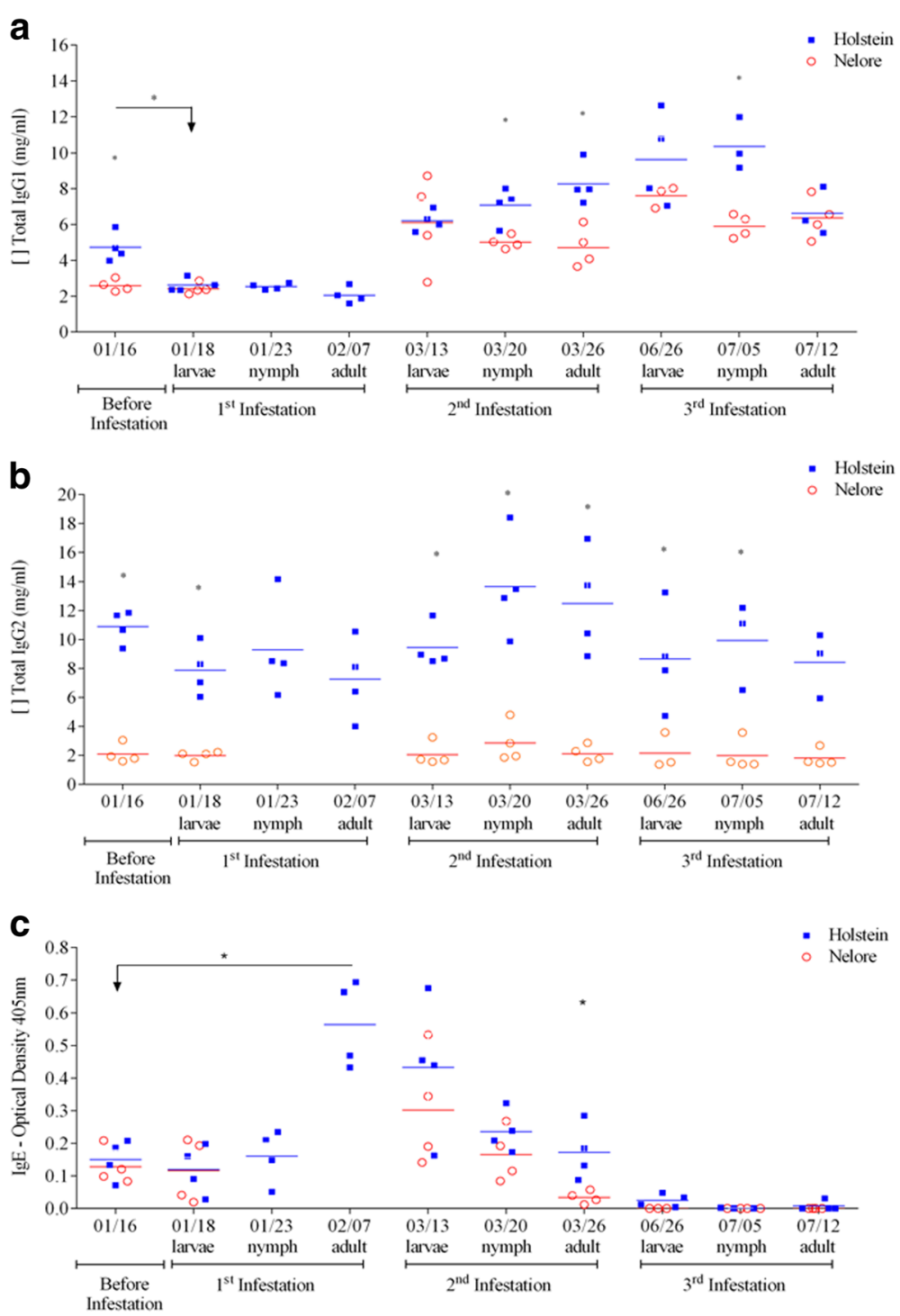

Fig. 1 Amounts of total $\lg G 1, \lg G 2$ and lgE immunoglobulins differ between tick-resistant and tick-susceptible breeds of cattle. Amounts of total $\lg 1_{1}(\mathbf{a}), \lg \mathrm{g} 2$ (b) and lgE (c) immunoglobulins were measured in animals of a tick-susceptible (Holstein, blue squares) and a tick-resistant (Nelore, red open circles) breed of cattle before (baseline levels) and during three successive artificial infestations with ticks, when parasites were at the larval, nymphal and adult stages of their life-cycle. Dilutions of sera employed in indirect ELISAs were 1:100 and 1:5 for total lgG1 and lgG2, and for total lgE, respectively. Asterisks indicate the levels of significance between amounts of total $\lg G 1, \lg G 2$ and $\lg E$ immunoglobulins from Holstein and Nelore hosts and the specific statistical results are described in the text

Holsteins than in Nelores during the three successive infestations (Fig. 1b).

Relative to baseline levels, levels of total IgE increased significantly (ANOVA, $F_{(1.463,4.389)}=13.94, P=0.0144$ ) in the tick-susceptible breed at the end of the first and beginning of the second infestations (Fig. 1c); the levels of total IgE in the resistant breed also increased during the second infestation, but the differences were not significant (Fig. 1c). Interestingly, in both breeds levels of total IgE tended to decrease during successive infestations (Fig. 1c). By the third infestation, the levels of total IgE had returned to basal levels in both breeds (Fig. 1c).
In summary, the levels of total IgG1 and IgG2 immunoglobulins are higher in the susceptible breed before and during infestations, whereas the levels of total IgE are always similar in both breeds.

Levels of tick salivary protein-specific IgG1 and IgG2 antibodies differ in genetically tick-susceptible and tick-resistant hosts after successive infestations

The significant increase in levels of total IgG1 and IgG2 seen in susceptible hosts after they are infested with ticks could be due to production of IgG antibodies in response to salivary antigens that ticks salivate into their 
hosts. We therefore measured the levels of IgG1 and IgG2 antibodies specific for saliva from female ticks and for extracts of FSG in sera from resistant (i.e. Nelore) and susceptible (Holstein) hosts that had been kept free of ticks and were then infested artificially three times with 10,000 unfed larvae. Susceptible bovine hosts theoretically receive much larger quantities of female saliva than resistant hosts due to the significantly higher number of ticks finishing their life-cycle on them. In spite of these differences in tick loads, and despite the fact that tick-resistant bovines present with significantly lower levels of total IgG1 immunoglobulins than susceptible hosts, we verified that before exposure to ticks and at the beginning of the first infestation, levels of saliva- and FSG-specific IgG1 antibodies were significantly ( $t$-test, $t_{(3.876)}=6, P=0.0082$ and $t_{(4.186)}=6, P=0.0058$, respectively) higher in tick-resistant hosts than in tick-susceptible hosts (Fig. 2a, b). Titration of sera in an end-point dilution assay confirmed these results (data not shown). However, by the third infestation, susceptible hosts produced significantly (saliva: $t$-test, $t_{(4.876)}=5, P=0.0046$ and $t_{(3.182)}=5$, $P=0.0245$, nymphal and adult stages, respectively; FSG: $t$ test, $t_{(7.667)}=5, P=0.0006, t_{(4.495)}=5, P=0.0064$ and $t_{(5.779)}=5, P=0.0022$, larval, nymphal and adult stages, respectively) higher levels of saliva- and FSG-specific IgG1 antibodies than resistant hosts (Fig. 2a, b). In all, these findings indicate that, in susceptible animals, levels of tick-specific antibodies begin to correlate with tick loads only after successive infestations. They also indicate that upon primary and subsequent exposures to ticks, resistant animals maintain consistent levels of antibodies specific for saliva and FSG.

Resistant and susceptible hosts presented with similar levels of saliva- and FSG-specific IgG2 antibodies before and during the first two artificial infestations (Fig. 3a, b). Relative to baseline levels, during the third infestation FSG-specific IgG2 antibodies increased significantly (ANOVA, $F_{(1.828,3.656)}=22.30, P$
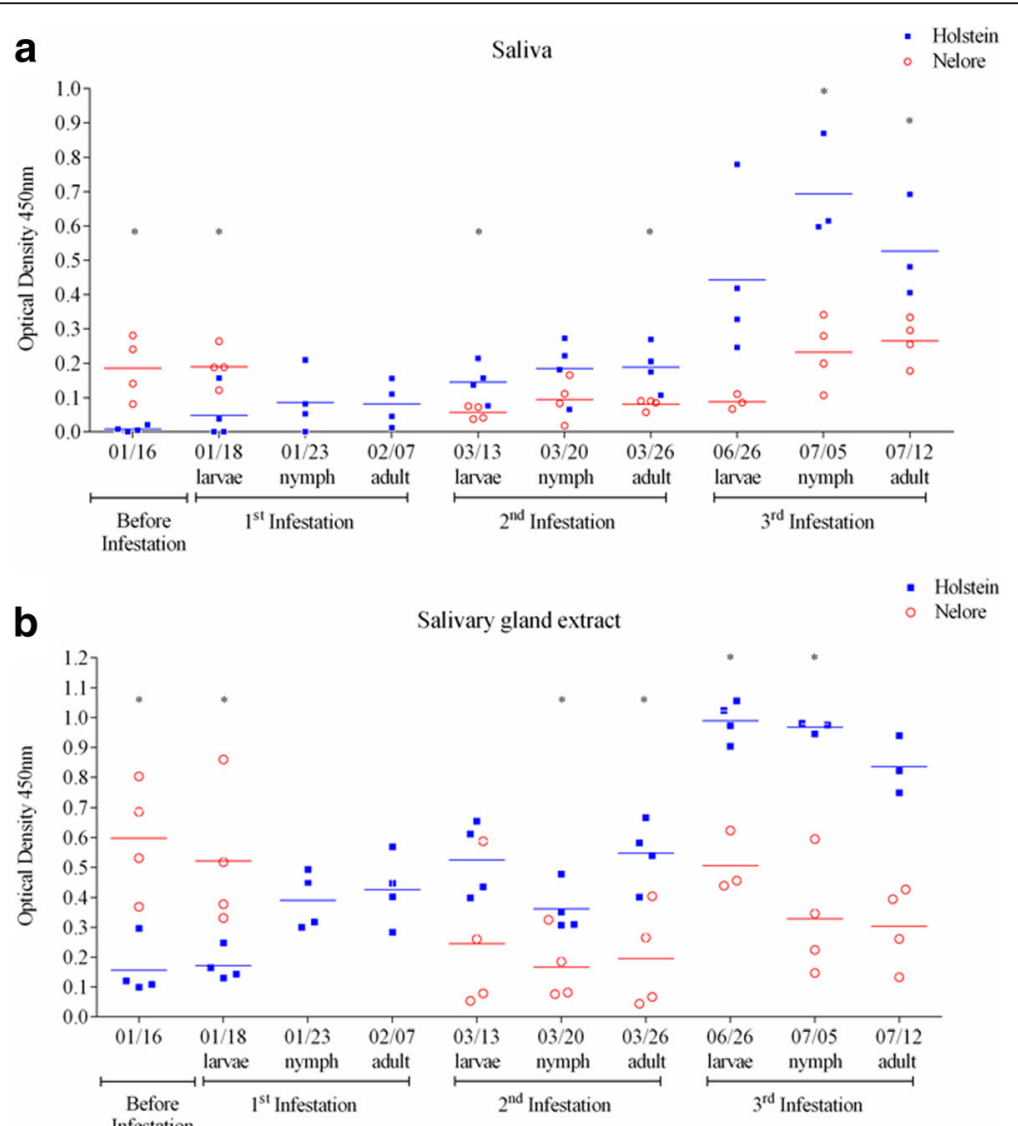

Fig. 2 Levels of lgG1 antibodies specific for saliva and extracts of salivary glands from female ticks differ between tick-resistant and tick-susceptible breeds of cattle after successive infestations with $R$. microplus. Levels of IgG1 antibodies specific for saliva (a) and for salivary gland extracts from female ticks (b) were measured in sera from animals of a tick-susceptible (Holstein, blue squares) or tick-resistant (Nelore, red open circles) breed of cattle. Antibodies were measured before (baseline levels) and during three successive artificial infestations with ticks, when the parasites were at the larval, nymphal and adult stages of their life-cycle. A dilution of 1:100 was used for each serum. Asterisks indicate the levels of significance between amounts of specific lgG1 antibodies in Holstein and Nelore hosts and the specific statistical results are described in the text 

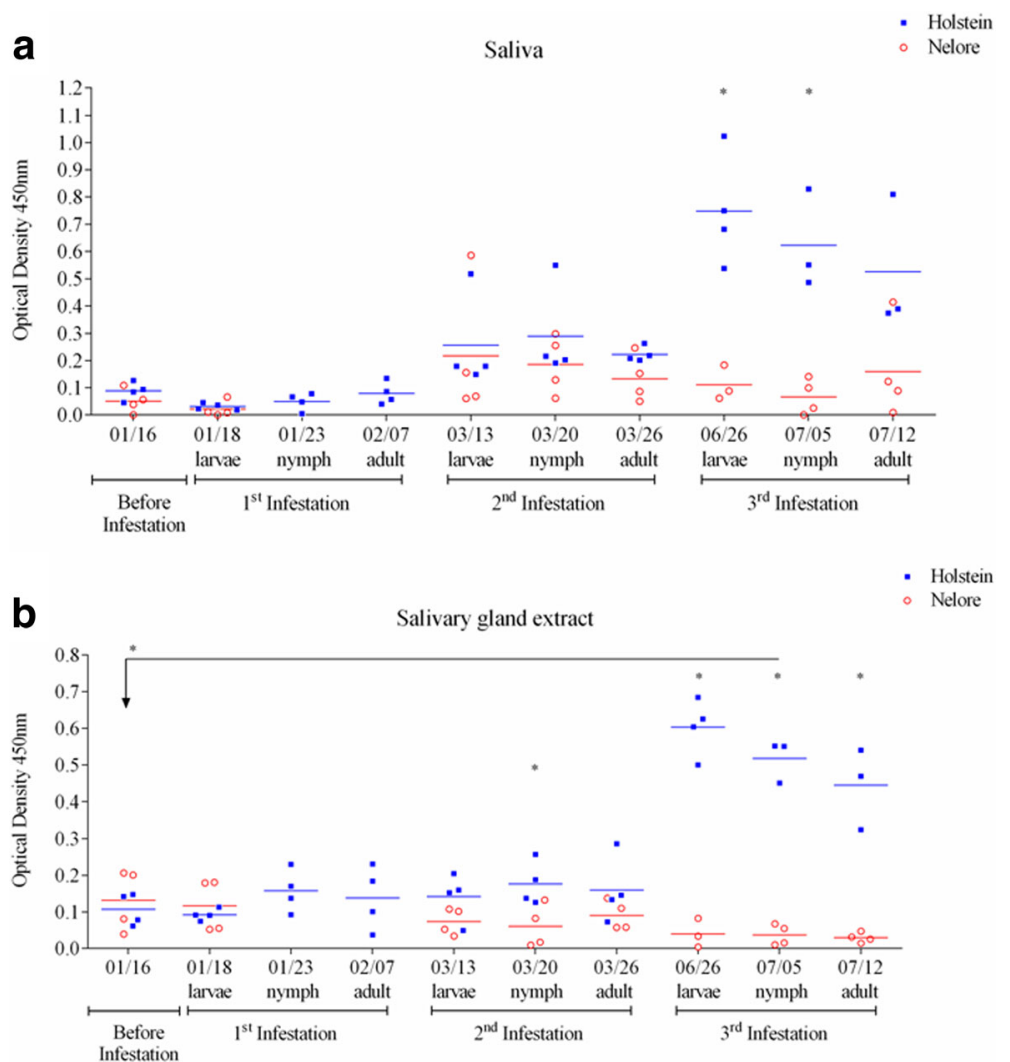

Fig. 3 Levels of lgG2 antibodies specific for saliva and extracts of salivary glands from female ticks differ between tick-resistant and tick-susceptible breeds of cattle. Levels of lgG2 antibodies specific for saliva (a) and for salivary gland extracts from female ticks (b) were measured in sera from animals of a tick-susceptible (Holstein, blue squares) or tick-resistant (Nelore, red open circles) breed of cattle. Antibodies were measured before (baseline levels) and during three successive artificial infestations with ticks, when the parasites were at the larval, nymphal and adult stages of their life-cycle. A dilution of 1:100 was used for each serum. Asterisks indicate the levels of significance between amounts of specific lgG2 antibodies in Holstein and Nelore hosts and the specific statistical results are described in the text

$=0.0092)$ in susceptible hosts undergoing infestations with nymphs (Fig. 3b). In addition, by the third infestation and during all developmental stages of ticks, susceptible hosts presented with significantly ( $t$-test, $t_{(11.43)}=5, P<0.0001, t_{(14.67)}=5, P<0.0001$ and $t_{(7.723)}$ $=5, P=0.0006$, respectively for the larval, nymphal and adult stages) higher levels of FSG-specific IgG2 antibodies when compared with resistant hosts (Fig. 3b). Similar differences were seen between levels of saliva-specific IgG2 antibodies in resistant and susceptible bovines (Fig. 3a).

In summary, upon the first exposure to ticks, resistant bovines present significantly higher levels of female salivary protein-specific IgG1 antibodies, but not of IgG2 antibodies when compared with susceptible bovines undergoing the same level of exposure. Conversely, successive infestations in susceptible bovines are accompanied by a continual increase in the levels of female salivary protein-specific IgG1 and IgG2 antibodies.
Antibodies from tick-resistant hosts recognize a larger repertoire of tick salivary proteins than antibodies from susceptible hosts

While levels of immunoglobulins and of saliva-specific antibodies differ between the breeds of bovine hosts and are associated with the size of the tick loads, the specificities of the antibodies for individual proteins are not known. We thus examined the specificities of antibodies produced by the two types of bovine hosts to tick salivary proteins resolved in one (Fig. 4) and two dimensions (Fig. 5). Figure 4a presents the complete profiles of proteins obtained with extracts of female and male salivary glands and of unfed larvae originating from ticks fed on susceptible or resistant hosts resolved in one dimension; Fig. $4 \mathrm{~b}$ presents the profiles of reactivity against these tick proteins with antibodies from resistant and susceptible bovines undergoing all developmental stages of the second successive infestation with $R$. microplus. The profiles show that, in spite of presenting lower tick loads and lower levels of IgG1 and IgG2 antibodies specific for 

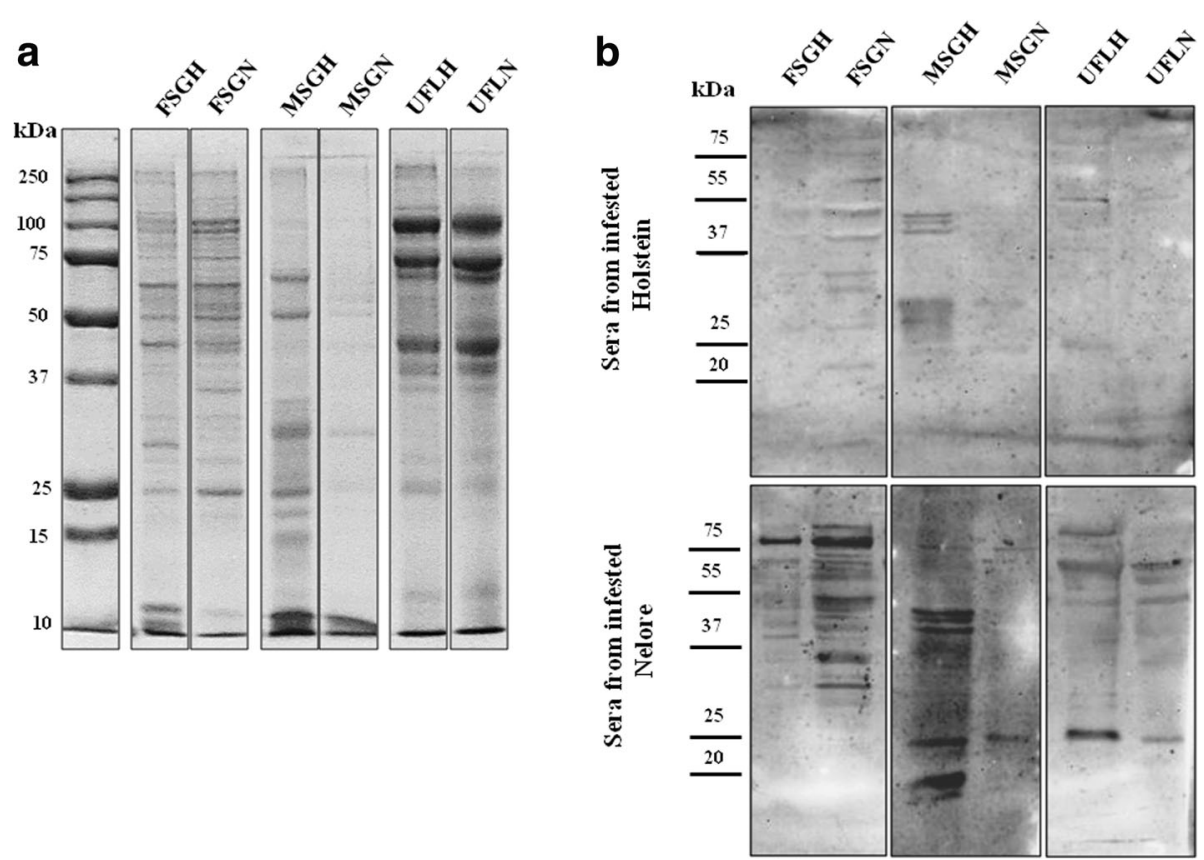

Fig. 4 Sera from twice-infested, genetically tick-resistant breeds of bovines react with more tick salivary proteins than sera from genetically tick-susceptible bovines. a Protein extracts of FSG, MSG and UFL (7 $\mu \mathrm{g}$ of each) from ticks fed on resistant (R) and susceptible (H) hosts were separated in 12\% SDS-PAGE gels and then stained with Coomassie blue. Molecular weight markers (kDa) are indicated on the left of the gel. b Sera were reacted in protein blots of extracts of FSG, MSG and UFL of R. microplus separated by electrophoresis in one dimension. Sera were pooled from twice-infested, tick-susceptible (Holstein breed) or tick-resistant (Nelore breed) bovines ( $N=4$ of each) when infested with larvae, nymphs and adults, totaling 12 sera in each pool) and reacted with proteins from the indicated extracts. The end dilution used was 1:75. Abbreviations: FSGH, extract of salivary glands from female ticks fed on Holsteins; FSGN, extract of salivary glands from female ticks fed on Nelores; MSGH, extract of salivary glands from male ticks fed on Holsteins; MSGN, extract of salivary glands from male ticks fed on Nelores; UFLH, extract of larvae hatched from egg masses laid by female ticks fed on Holsteins; UFLN, extract of larvae hatched from egg masses laid by female ticks fed on Nelores

extracts of salivary proteins, sera from animals of the tick-resistant breed (Nelores) recognize a much larger range of tick proteins, some of which with greater intensity than sera from susceptible hosts (Fig. 4b). Interestingly, we also observed that reactivity profiles of sera with extracts of salivary glands from ticks fed on either resistant or susceptible hosts differed, indicating that the composition of these extracts also varies and, therefore, that ticks modify their salivary protein repertoire according to the host that they feed on (Fig. 4a).

\section{Immunoblot analyses of $R$. microplus salivary antigens separated in two dimensions: sera from resistant bovine hosts react with a broader range of proteins related to putative functions of parasitism}

We identified tick salivary proteins that are differentially recognized by the two types of host by resolving in two dimensional electrophoresis saliva from female ticks feeding on tick-susceptible bovine hosts, followed by spot picking and sequencing by LC-MS and running in parallel gels for immunoblots with informative the sera. We succeeded in identifying proteins from a total of 101 spots in 2-D gels (Additional file 2: Table S2). Of these spots, 64 were reactive with at least one group of pooled sera and 55 did not react with sera from any group. The results presented in Fig. 5 and Table 1 show that 8 spots were recognized by all groups of sera; putative functions of proteins identified were those of a Kunitz inhibitor, a serpin, a tropomyosin and cathepsin D2, among others.

Pooled sera from tick-resistant Nelores reacted with twice the number of spots than pooled sera from ticksusceptible Holsteins, 39 vs 21 spots, respectively (Fig. 5 and Table 1). Among putative functions of proteins in spots reacting exclusively with sera from tick-resistant Nelores were an apolipophorin, a salivary lipid interacting protein, histamine-binding proteins, protein disulfide isomerases, serpin-3, and vitellogenins.

Many proteins encoded by the same CDS (BioProject ID PRJNA329522) were present in more than one spot, but were recognized by sera from either resistant or susceptible bovines. For example, a cathepsin L-like cysteine proteinase $\mathrm{B}$ and a longipain, encoded by CDS39114 and CDS122308, respectively, were both found in three distinct spots, two of which reacted exclusively with pooled sera from infested Nelores and one with sera from infested Holsteins and Nelores. 


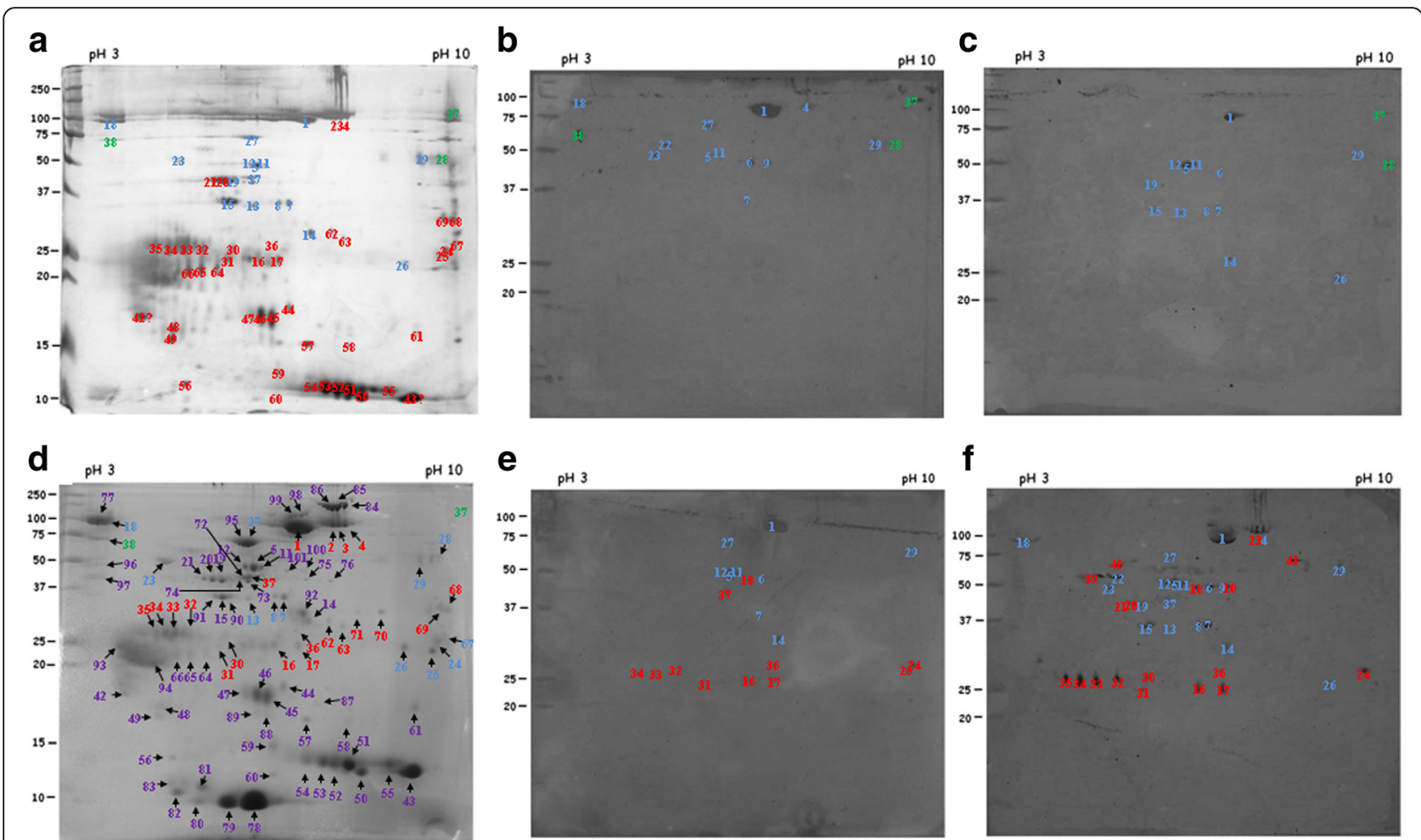

Fig. 5 Identification of salivary proteins from $R$. microplus that react with sera from tick-susceptible and tick-resistant bovines. A pool of saliva collected from female ticks feeding on genetically susceptible hosts was focalized on $13 \mathrm{~cm} \mathrm{pH3-10} \mathrm{L} \mathrm{(left} \mathrm{to} \mathrm{right)} \mathrm{strips} \mathrm{in} \mathrm{the} \mathrm{first} \mathrm{dimension} \mathrm{and} \mathrm{12 \%} \mathrm{SDS-PAGE} \mathrm{gels} \mathrm{in}$ the second dimension. Molecular weight markers are indicated on the left ( $\mathrm{kDa})$. a Gel stained with silver. $\mathbf{b}$-f Gels run in parallel with the gel shown in (a) were transferred to nitrocellulose membranes, incubated with pooled sera diluted 1:100 from susceptible (Holstein breed: $\mathbf{b}$ and $\mathbf{c}$ ) or resistant (Nelore breed: $\mathbf{e}$ and $\mathbf{f}$ ) hosts, before (non-infested) and after infestation (larva, nymph and adult stages), respectively, and developed with protein-G conjugated with peroxidase (diluted 1:2000). Reactive spots are highlighted (d) and were excised separately and analyzed by MS. Results are shown in Table 1

Among the spots that reacted exclusively with sera from susceptible, infested bovines was one that contained a glutathione S-transferase. Another glutathione S-transferase encoded by a distinct CDS reacted exclusively with sera from both naïve and infested Nelores, being that the enzyme recognized by Nelore sera presented a pI and a MW that differed from that of the functionally similar enzyme recognized by sera from susceptible bovines.

\section{Discussion}

Cattle ticks are able to remain on their bovine hosts for approximately three weeks and during this period they ingest relatively large amounts of blood containing antibodies. Many of these antibodies are potentially specific for tick saliva, especially in repeatedly infested hosts. The present study examined antibody responses to $R$. microplus ticks in a model of bovines presenting contrasting phenotypes of infestations and undergoing artificial infestations: it examines levels of total IgG1, IgG2 and $\operatorname{IgE}$ as well as the specific antibody responses and profiles of reactivities to different sets of tick salivary antigens.

We first showed that levels of total IgG1 and IgG2 immunoglobulins are higher in the susceptible breed before and during infestations. This finding concurs with the observations made by Rechav [37], who followed immunoglobulin levels for thirty-six months and showed that concentrations of gamma globulins were consistently higher in bovines of the tick-susceptible, Hereford taurine breed than in the tick-resistant, Brahman indicine breed. Rechav [37] also found a positive correlation between the number of adult ticks removed from hosts and levels of immunoglobulins. In the present study, during the first infestation, levels of total IgG1 and IgG2 decreased in tick-susceptible Holsteins, but did not change significantly in tick-resistant Nelore hosts. The decrease seen in Holsteins cannot be attributed to the action of tick salivary IgG-binding proteins since it was patent two days after larvae were released and this mediator of parasitism is produced solely by male ticks [40], including in $R$. microplus [32]. On the other hand, tick infestations cause stress to their hosts $[41,42]$ and levels 
Table 1 Salivary proteins of female $R$. microplus ticks recognized by sera from naïve and/or two-times infested genetically tick-susceptible and/or tick-resistant bovines

\begin{tabular}{|c|c|c|c|c|}
\hline Spot No. in figure & CDS in sialotranscriptome ${ }^{a}$ & Annotation and putative function of protein & MW Kda ${ }^{b}$ & Source of pooled reactive sera ${ }^{c}$ \\
\hline 34 & 20757 & 14-3-3 CG17870-PA, isoform A isoform 2 & 27 & NR IR \\
\hline 33 & 20757 & 14-3-3 CG17870-PA, isoform A isoform 2 & 27 & NR IR \\
\hline 20 & 18420 & actin & 42 & $\mathbb{I R}$ \\
\hline 21 & 18420 & actin & 42 & $\mathbb{R}$ \\
\hline 19 & 18420 & actin & 42 & IR IS \\
\hline 22 & 18420 & actin & 42 & IR NS \\
\hline 1 & 109972 & anticoagulant protein rhipilin-1 & 17 & NR IR NS IS \\
\hline 37 & 31546 & apolipophorin & 89 & NR IR \\
\hline 18 & 31546 & apolipophorin & 89 & NR IR \\
\hline 22 & 7197 & beta tubulin & 53 & IR NS \\
\hline 22 & 22306 & beta tubulin & 50 & IR NS \\
\hline 22 & 22310 & beta tubulin & 35 & IR NS \\
\hline 29 & 14491 & cathepsin D2 & 42 & NS IS NR IR \\
\hline 20 & 39114 & cathepsin L-like cysteine proteinase B & 38 & IR \\
\hline 21 & 39114 & cathepsin L-like cysteine proteinase B & 38 & $\mathbb{R}$ \\
\hline 19 & 39114 & cathepsin L-like cysteine proteinase B & 38 & IR IS \\
\hline 1 & 50205 & CBF1-interacting corepressor & 30 & NR IR NS IS \\
\hline 40 & 30215 & chaperonin subunit & 65 & $\mathbb{R}$ \\
\hline 9 & 111414 & CRISP3-cysteine-rich secretory protein & 46 & IR NS \\
\hline 30 & 25106 & enolase & 43 & $\mathbb{I R}$ \\
\hline 24 & 67998 & ENSANGP00000022132 & 25 & NR IR \\
\hline 22 & 4388 & FOF1-type ATP synthase, beta subunit & 59 & IR NS \\
\hline 25 & 111630 & glutathione S-transferase & 31 & $N R$ \\
\hline 24 & 111630 & glutathione S-transferase & 31 & NR IR \\
\hline 38 & 21956 & heat shock protein & 71 & NS \\
\hline 37 & 4142 & heavy-chain filboin & 44 & NR IR \\
\hline 14 & 71787 & hypothetical protein & 22 & NR IR IS \\
\hline 1 & 110513 & hypothetical protein & 3 & NR IR NS IS \\
\hline 38 & 121267 & hypothetical protein BRAFLDRAFT_287019 & 45 & NS \\
\hline 20 & 122308 & longipain cystein protease & 33 & $\mathrm{IR}$ \\
\hline 21 & 122308 & longipain cystein protease & 33 & IR \\
\hline 19 & 122308 & longipain cystein protease & 33 & IR IS \\
\hline 13 & 113489 & lospin 8 type serpin & 43 & IR IS \\
\hline 12 & 113489 & lospin 8 type serpin & 43 & NR IR IS \\
\hline 11 & 113489 & lospin 8 type serpin & 43 & NR IR NS IS \\
\hline 6 & 113489 & lospin 8 type serpin & 43 & NR IR NS IS \\
\hline 7 & 113489 & lospin 8 type serpin & 43 & NR IR NS IS \\
\hline 10 & 113489 & lospin 8 type serpin & 43 & $\mathbb{R}$ \\
\hline 8 & 113489 & lospin 8 type serpin & 43 & IR IS \\
\hline 5 & 113489 & lospin 8 type serpin & 43 & NR IR IS \\
\hline 11 & 171727 & lysosomal acid phosphatase & 26 & NR IR NS IS \\
\hline 40 & 9166 & protein disulfite isomerase-2 & 39 & $\mathbb{R}$ \\
\hline 40 & 10534 & protein disulfite isomerase- 2 & 39 & $\mathbb{R}$ \\
\hline
\end{tabular}


Table 1 Salivary proteins of female $R$. microplus ticks recognized by sera from naïve and/or two-times infested genetically tick-susceptible and/or tick-resistant bovines (Continued)

\begin{tabular}{|c|c|c|c|c|}
\hline 12 & 39744 & putative chitinase & 45 & NR IR IS \\
\hline 15 & 128399 & putative salivary secreted protein & 36 & IR IS \\
\hline 24 & 83247 & putative salivary secreted protein & 25 & $N R I R$ \\
\hline 14 & 77570 & putative salivary secreted protein & 25 & NR IR IS \\
\hline 14 & 85307 & putative salivary secreted protein & 27 & NR IR IS \\
\hline 35 & 108605 & putative secreted protein & 24 & $\mathbb{R}$ \\
\hline 35 & 171393 & putative secreted protein & 18 & $\mathbb{R}$ \\
\hline 32 & 171393 & putative secreted protein & 18 & $N R I R$ \\
\hline 33 & 171393 & putative secreted protein & 18 & $N R I R$ \\
\hline 34 & 171393 & putative secreted protein & 18 & $N R I R$ \\
\hline 30 & 174664 & putative secreted protein (histamine-binding?) & 21 & $\mathbb{R}$ \\
\hline 31 & 174664 & putative secreted protein (histamine-binding?) & 21 & $N R I R$ \\
\hline 32 & 174664 & putative secreted protein (histamine-binding?) & 21 & $N R I R$ \\
\hline 33 & 174664 & putative secreted protein (histamine-binding?) & 21 & $N R I R$ \\
\hline 34 & 174664 & putative secreted protein (histamine-binding?) & 21 & $N R I R$ \\
\hline 31 & 178127 & putative secreted protein (histamine-binding?) & 21 & $N R I R$ \\
\hline 33 & 178127 & putative secreted protein (histamine-binding?) & 21 & $N R I R$ \\
\hline 34 & 178127 & putative secreted protein (histamine-binding?) & 21 & $N R I R$ \\
\hline 35 & 178127 & putative secreted protein (histamine-binding?) & 21 & $\mathbb{R}$ \\
\hline 14 & 54776 & putative thyropin precursor & 23 & NR IR IS \\
\hline 17 & 113785 & salivary lipid interacting protein & 20 & $N R I R$ \\
\hline 36 & 113785 & salivary lipid interacting protein & 20 & $N R I R$ \\
\hline 16 & 113785 & salivary lipid interacting protein & 20 & $N R I R$ \\
\hline 8 & 38904 & secreted protein & 38 & IR IS \\
\hline 31 & 164102 & secreted protein & 23 & $N R I R$ \\
\hline 31 & 164103 & secreted protein & 23 & $N R I R$ \\
\hline 33 & 164103 & secreted protein & 23 & $N R I R$ \\
\hline 7 & 38904 & secreted protein & 38 & NR IR NS IS \\
\hline 16 & 128399 & secreted protein & 36 & $N R I R$ \\
\hline 17 & 128399 & secreted protein & 36 & $N R I R$ \\
\hline 26 & 8103 & secreted salivary gland peptide & 25 & $I S \mid R$ \\
\hline 25 & 8103 & secreted salivary gland peptide & 25 & NR \\
\hline 24 & 8103 & secreted salivary gland peptide & 25 & $N R I R$ \\
\hline 27 & 8103 & secreted salivary gland peptide & 25 & NR IR NS \\
\hline 24 & 26121 & selenium-dependent salivary glutathione peroxidase & 18 & $N R I R$ \\
\hline 20 & 106322 & serine proteinase inhibitor serpin-3 & 43 & $\mathbb{R}$ \\
\hline 21 & 106322 & serine proteinase inhibitor serpin-3 & 43 & $\mathbb{R}$ \\
\hline 19 & 106322 & serine proteinase inhibitor serpin-3 & 43 & IR IS \\
\hline 30 & 106322 & serine proteinase inhibitor serpin-3 & 43 & $\mathbb{R}$ \\
\hline 20 & 106321 & serine proteinase inhibitor serpin-3 & 43 & $\mathbb{R}$ \\
\hline 19 & 106321 & serine proteinase inhibitor serpin-3 & 43 & IR IS \\
\hline 12 & 6955 & serpin-2 precursor & 36 & NR IR IS \\
\hline 28 & 13343 & translation elongation factor EF-1 alpha-Tu & 51 & NS IS \\
\hline 29 & 13343 & translation elongation factor EF-1 alpha-Tu & 51 & NS IS NR IR \\
\hline
\end{tabular}


Table 1 Salivary proteins of female R. microplus ticks recognized by sera from naïve and/or two-times infested genetically tick-susceptible and/or tick-resistant bovines (Continued)

\begin{tabular}{llll}
\hline 31 & 32190 & uncharacterized protein & NR IR \\
37 & 43507 & vitellogenin-1 & NR IR \\
18 & 43508 & vitellogenin-1 & NR IR \\
18 & 43509 & vitellogenin-1 & NR IR \\
\hline
\end{tabular}

Note: The table is formatted according to annotation of putative function of protein, but not by spot number recovered from gel. In some instances there are more than one protein identified in the spot collected

${ }^{a}$ CDS: coding sequences generated by the sialotranscriptome of R. microplus and deposited at GenBank - NCBI (BioProject ID PRJNA329522)

${ }^{\mathrm{b}}$ Molecular weight furnished by Scaffold software

${ }^{c}$ Abbreviations for sources of sera and samples: NR, pooled sera collected from four tick-naïve, genetically resistant Nelore; IR, pooled sera from four genetically resistant, twice-infested Nelore bovines at the end of the infestation; NS, pooled sera collected from four tick-naïve, genetically susceptible Holstein bovines; IS, pooled sera from four genetically susceptible, twice-infested Holstein bovines at the end of the infestation

Salivary proteins were obtained from saliva of female $R$. microplus ticks feeding on genetically susceptible hosts. Sera employed were obtained from naïve and/or two-times infested genetically tick-susceptible and/or tick -resistant bovines. Criteria employed to identify each sequence: minimum of one peptide presenting with $90 \%$ probability of being the protein and $90 \%$ probability of being the peptide

of cortisol are known to be inversely related to levels of serum immunoglobulins in bovines [43]. Levels of serum immunoglobulins are also inversely correlated with their half-life due to the phenomenon of concentrationcatabolism, in which the availability of the IgG salvage receptor (or neonatal Fc receptor, FcRn) determines the serum concentration of IgG [44, 45]. Of relevance to this study, functional FcRn is produced by keratinocytes in skin $[46,47]$ and is detected in epithelial cells of the hair follicles and sebaceous glands and in melanocytes [47]; in phagocytic cells it can be upregulated by TNF-alpha [48] and downregulated by IFN-gamma [49]. Furthermore, tick infestations induce acute phase responses [41], in which the levels of a large set of proteins increase or decrease. Some of these proteins have been shown to bind to immunoglobulin $\mathrm{Fc}$ receptors of phagocytic leukocytes [50] and we speculate that they may affect levels of IgGs by altering the availability of salvage FcRn or catabolic FcR.

Regarding levels of total IgE, these did not differ between bovine breeds examined in this study. However, they were affected by tick infestations in both breeds: they increased during successive infestations, but by the third infestation had returned to basal levels. Once explanation for this finding is the fact that IgE has a shorter half-life than IgG and the observed decline thus results from the rapid catabolism of this class of antibody. It is also possible that this decrease was caused by recruitment of homocytotropic IgE antibodies to the site of tick attachment and/or recruitment of IgE secreting-cells in this site. Indeed, IgG is found deposited near tick attachment sites in the skin of tick-resistant guinea-pigs [51].

Beekeepers develop immune tolerance by after repeated exposure to bee venom, which is also delivered through the skin [52]: in spite of detectable levels of venom-specific IgE, titers of venom-specific IgG4 antibodies reach extremely high levels at the end of the beekeeping season and are positively correlated with levels of venom antigen-specific $\mathrm{T}$ regulatory cells, which increase upon persistence of the antigen and return to initial levels within a few months after individuals are no longer exposed to stings. The equivalent of allergenblocking IgG4 antibodies has not been described in cattle, but it is intriguing that in spite of high levels of challenge with tick saliva, levels of IgE decreased during the third round of infestation.

Regarding levels of saliva and FSG extract-specific IgG1 and IgG2 antibodies, upon the first exposure to ticks, resistant bovines present significantly higher levels of IgG1 antibodies, but not of IgG2 antibodies, compared with susceptible bovines undergoing the same level of exposure and, after subsequent exposure, resistant animals maintain the same levels of antibodies. Successive infestations in susceptible bovines were accompanied by a continual increase in the levels of IgG1 and IgG2 antibodies specific for saliva or for extracts of salivary glands from female ticks.

Successive infestations in $\mathrm{C} 3 \mathrm{H} / \mathrm{HeJ}$ mice polarize the $\mathrm{T}$ helper cellular response towards a $\mathrm{TH} 2$ phenotype, but the profile of corresponding antibody responses in that situation was not examined [53]. Nevertheless, in the present work the antibody profiles in both breeds of bovines do not point towards a polarized helper $\mathrm{T}$ lymphocyte response because levels of saliva and SGEspecific IgG1 and IgG2 antibodies were similar. Menten-Dedoyart and colleagues [54] examined antibody responses specific for bovine serum albumin (BSA) made by BALB/c mice artificially infested with a single couple of adult Ixodes ricinus before or after immunization with this antigen. They observed that infestations did not affect the ratio of IgG1 to IgG2 antiBSA antibodies. These authors also demonstrated that infestations inhibited production of antibodies by plasma cells, but not the development of B memory cells since recall antibody responses were similar to those seen in non-infested, control mice [55].

A study by Piper and colleagues [27] examined differences in antibody responses mounted by tick-resistant 
Brahmans and susceptible Holsteins that were infested artificially and had been exposed to ticks since birth. In contrast to the results obtained in the present study, Piper et al. [27] found that IgG1, but not IgG2 tickspecific antibodies were significantly higher in susceptible hosts than in resistant hosts. This discrepancy may be caused by differences in the experimental designs of the two studies: our study employed whole saliva from female ticks as the antigen for measuring antibodies and not two types of fractions from extracts of salivary glands (membrane-bound and soluble); in addition Piper et al. [27] did not describe the origin of the anti-bovine IgG1 and IgG2 antibodies employed in their assays and differences in IgG allotypes recognized by the reagents from different manufacturers may affect results from each laboratory. Previous work by some of us [25] showed that the IgG1 and IgG2 antibody responses to tick saliva in naturally infested bovines were significantly decreased in susceptible hosts when pastures were highly infested compared to these same hosts when pastures were lightly infested. Levels of these antibodies remained stable in resistant hosts regardless of the intensity of infestation of the pasture. In that study cattle were exposed to thousands of larvae produced by hundreds of females dropped from the hosts; in the case of the present study hosts were infested with 10,000 larvae produced by a few females.

We also sought to identify the proteins recognized differentially by the two types of host. We succeeded in identifying proteins from a total of 101 spots from saliva in 2-D gels followed by LC-MS. Many of the proteins identified in our immunoproteome have already been identified in a salivary proteome of $R$. microplus [56], as well as in those of other species of ticks [57-60]. Tirlone et al. [56] compared the profile of saliva of partially and fully engorged females of $R$. microplus fed on Hereford calves; the proteomic analysis employed 1D gel electrophoresis and LC-MS/MS. They identified 187 different tick salivary proteins, as well as 68 proteins from the bovine host [56]. The authors also showed that protein profile of saliva changes according the stage of feeding and identified proteins that were found exclusively in partially or fully engorged females and others that were shared between these stages. Similar findings were obtained with Haemaphysalis longicornis ticks fed on rabbits, where 135 proteins were present in the saliva of both nymph and female ticks, of which 30 proteins were identified exclusively in fully saliva of engorged nymphs, 74 in saliva of fully engorged females, and 31 were detected in both instars [57]. Oliveira et al. [58] compared the protein profile of saliva from Rhipicephalus sanguineus female ticks fed on rabbits which had been collected with two salivation stimulants (dopamine and pilocarpine) and proteomic analysis employed 1D gel electrophoresis followed by reversed-phase HPLC and MS/MS analysis. Their study showed that saliva obtained with pilocarpine presented with more proteins than when obtained with dopamine; however, few proteins associated with parasitism and blood-feeding were identified. A similar study using salivary glands from female Amblyomma variegatum ticks fed on B. indicus was performed using 1D gel electrophoresis followed by nanoflow reverse-phase liquid chromatography tandem mass spectrometry [60]; this study also identified only a few tick proteins that could be associated with parasitism. Díaz-Martín et al. [59] performed a proteomic study comparing saliva from females and males of Ornithodoros moubata ticks with LC-MS/MS. They identified 193 proteins and there was a notable difference in the proteomes of females and males, with few proteins shared by both sexes. On the other hand, our proteomic approach employing 2D gel followed by mass sequencing was able to identify a larger number of proteins associated with parasitism and hematophagy when compared with $1 \mathrm{D}$ gel approaches followed by mass sequencing. Moreover, the saliva used in these other proteomic studies were obtained from different species of ticks and developmental stages of ticks as well as ticks fed on different hosts, resulting in different protein profiles. Nevertheless, we observed that these different saliva presented numerous proteins in common including several conserved and structural proteins (actin, tubulin and others), besides salivary proteins that potentially participate in parasitism, such as those containing Kunitz or ML domains, antimicrobial peptides, serpins, lipocalins, cystatins, tryropins, glycine-rich proteins, mucins, chitinases, disulfide isomerase cathepsin, glutathione peroxidases, vitellogenin and others [56-60]. However, none of these previous proteomic studies identified neutrophil elastase inhibitors as we have found in the present study.

In the present report, among the 101 proteins identified, 8 spots were recognized by all groups of sera; putative functions of proteins identified were those of a Kunitz inhibitor, a serpin, a tropomyosin and cathepsin D2, among others. Noteworthy was the finding that tickresistant Nelores reacted with twice the number of spots than pooled sera from tick-susceptible Holsteins, 39 versus 21 spots, respectively. Among putative functions of proteins in spots reacting exclusively with sera from tick-resistant Nelores were an apolipophorin, a salivary lipid interacting protein, histamine-binding proteins (i.e. lipocalins), protein disulfide isomerases, serpin-3, and vitellogenins. Interestingly, as pointed out above, these proteins are always present in salivary proteome studies of different species of ticks [56-60], so they can be considered good targets to compose a vaccine against multiple species of ticks. 
Insect apolipoproteins are homologous to mammalian apolipoprotein E, which is involved in LPS detoxification, phagocytosis and pattern recognition. Indeed, an insect apolipophorin has been shown to participate in recognition of beta-1,3-glucan molecular patterns and cellular encapsulation reactions [61]. The lipid interacting protein possesses an MD-2-related lipid-recognition (ML) domain that plays a role in the recognition of pathogens. This domain is also present in proteins from other arthropod pests, such as in the house-dust mite allergen proteins such as Der f 2 from Dermatophagoides farinae and Der p 2 from D. pteronyssinus [62]. The lipocalins as histamine-binding proteins have been found extensively in the transcriptome (BioProject ID PRJNA329522) and proteomes [56] from $R$. microplus ticks and other ticks [57-60, 63-65]. These proteins may remove histamine generated in local itching reactions to tick bites and this function may neutralized by antibodies and, thus, compromised in resistant bovine hosts. Indeed, Willadsen et al. [66] have proposed that the amount of histamine available locally in the skin may have a role in the resistance to ticks. Protein disulfide isomerases play a role in guiding correct protein folding through formation and breakage of disulfide bonds and chaperone activity. Silencing of these enzymes in ticks affects blood-feeding and oviposition and overall tick viability [67]. Thus, neutralization of these salivary proteins by antibodies may explain the poor outcome of the life-cycle of $R$. microplus in Nelore hosts. In accordance with results presented herein, Rodriguez-Valle and colleagues [68] showed that RMS-3, a serpin from $R$. microplus, reacts more intensely with sera from genetically resistant bovine hosts [68]. The vitellogenins recognized exclusively by sera of tickresistant hosts are also representatives of apoliproteins and contain lipid-binding domains, furthermore they participate in fertility of female ticks [69].

Many proteins encoded by the same CDS (BioProject ID PRJNA329522) were present in more than one spot and were individually recognized by different groups of sera. These patterns of reactivity may reflect that bovine hosts of different genetic compositions react with different post-translational modifications. Conversely, they may reflect different levels of antibodies between these groups of hosts, consequently affecting the sensibility of the immunoblotting assay. Among the spots that reacted exclusively with sera from susceptible, infested Holsteins was one that contained glutathione S-transferase, an enzyme that controls detoxification processes. Apparently, neutralization of these and other proteins by antibodies induced in genetically susceptible Holsteins does not confer significant advantages towards diminishing tick loads in these hosts. Another glutathione S-transferase encoded by a distinct CDS reacted exclusively with sera from Nelores, from both naïve and twice-infested animals. The significance of this finding in terms of resistance to ticks is not clear, but the enzymes recognized by Nelore sera presented a pI and a MW that differed from that of the enzyme recognized by sera from Holsteins.

In all, antibodies generated by Nelores before and after they were infested tended to react with proteins directly involved in mechanisms of parasitism and parasite escape mechanisms. In addition, antibodies generated by Nelores reacted with a greater number of tick salivary proteins. Indicine cattle may thus bear significantly lower tick loads because they neutralize more efficiently functions of tick saliva. Regarding the non-reactive components present in tick saliva and salivary gland extracts, Kotsyfakis et al. [70] have shown that these proteins can be rendered immunogenic with an adjuvant and that the elicited immune response subsequently affects tick biology. This indicates that these immunologically silent antigens are important in parasitism. The fact that some salivary proteins are immunogenic without exogenous intervention in some genetic backgrounds raises questions about the mechanisms behind this phenomenon. As mentioned previously herein, soluble proteins are immunogenic when they are aggregated or delivered with adjuvants $[23,24]$. Genetically tick-resistant hosts are either able to aggregate more tick salivary proteins and/or are more responsive to some form of signaling via components of innate immunity. Th2 responses to an antigen administered epicutaneously, the situation that occurs during tick infestations, are downregulated by the cleavage product of $\mathrm{C} 3$ convertase, $\mathrm{C} 3 \mathrm{a}$, produced at the site of injury to the skin [71]. Saliva from $R$. microplus ticks [72] can inhibit activation of complement, however to date a specific inhibitor of C3 convertase has been described in prostriate ticks [73], but not in $R$. microplus. In addition, the data described herein (see Figs. 2 and 3) do not indicate that antibody responses are polarized towards a specific phenotype of $\mathrm{T}$ lymphocytes. However, assays that measure levels of IgG1 and IgG2 antibodies specific for individual tick salivary antigens must be performed to confirm this finding.

Besides these possibilities, one must also consider that the balance of tick salivary components differs in ticks feeding on resistant and susceptible hosts (Fig. 4a) $[58,61]$. In both cases, several of these components have the potential to affect outcome of antigen recognition, processing and presentation, as well as assembly of effective immunity. For example, serpins affect assembly and outcome of immune responses mediated by $\mathrm{T}$ lymphocytes, including memory responses, by inhibiting enzymes of antigen processing and of cellular death programs. Importantly, pathogen-derived serpins also can inhibit the proteases involved in these processes (reviewed by Ashton-Rickardt [74]). As shown by us (BioProject ID 
PRJNA329522) and others [75-77], salivary glands of $R$ microplus contain a large repertoire of serpins and their role in modulating adaptive immune responses warrants further investigation. In addition, some tick salivary proteins tend to aggregate other proteins and to bind salivary proteins to host skin [78]. This has been shown to depend on an esterase and on a protease inhibitor. We have shown in this report that many protease inhibitors are well represented in tick saliva and in another report (BioProject ID PRJNA329522) that their rate of transcription differs according to the genetic background of the host that ticks feed on.

\section{Conclusions}

William Trager [79] was the first to show that sera passively transferred from tick-infested to non-infested guinea pigs subsequently challenged with ticks affected the infestation by decreasing engorgement of the ticks feeding on those hosts. Passive transfer of plasma from infested to non-infested hosts will only confer resistance to challenge infestations if the plasma is derived from genetically resistant animals [80]. These results show that there are qualitative and quantitative differences in humoral immune responses between susceptible and resistant hosts of ticks. In the present work, we measured the levels of total IgG1, IgG2 and IgE immunoglobulins and of saliva- and FSG-specific IgG1 and IgG2 antibodies in sera from tick-resistant and ticksusceptible host that were successively infested three times, followed by identification of tick antigens recognized differentially by sera from twice-infested hosts. The results show that susceptible animals have significantly higher levels of total IgG1 and IgG2 immunoglobulins than resistant hosts after successive infestations. On the other hand, susceptible hosts modulated levels of total IgG immunoglobulins and saliva- and FSG-specific IgG1 antibodies when infested for the first time with ticks. The innate humoral immune response that resistant hosts present upon a primary exposure to larvae may contain the infestations and increase the immunogenicity of salivary components. In humans, natural antibodies appear to be important in the immune responses against pathogens, since they have a high affinity for carbohydrate groups present in the membrane of many pathogens [81] and tick salivary proteins are glycosylated [82]. Another finding in this study is that, at the second successive infestation, the levels of total IgE increased in sera from both susceptible and resistant hosts and then decreased significantly at the third infestation. It is possible that this decrease was caused by recruitment of homocytotropic IgE antibodies to the site of tick attachment and/or recruitment of IgE secreting-cells in this site. A study that strengthens this hypothesis showed that IgG is found deposited near tick attachment sites in the skin of tick-resistant guinea-pigs [51]. Tolerance to tick salivary proteins, such as occurs against bee venom [52], is another possibility. Finally, our findings indicate that antibodies are related with resistance to ticks provided they react with a large repertoire of tick salivary proteins. The reasons for the greater immunogenicity of tick salivary proteins in genetically resistant hosts and/or the greater immunosuppressive capacity of tick saliva for susceptible hosts must now be investigated.

\section{Additional files}

Additional file 1: Table S1. Sera used in ELISA and proteome analyses. (DOCX 39 kb)

Additional file 2: Table S2. Identification of all spots recovered and sequenced from immunoblotting analyses using two-dimensional gel electrophoresis. (DOCX $57 \mathrm{~kb}$ )

\section{Abbreviations}

DTT: Dithiotreitol; EDTA: Ethylenediaminetetraacetic acid; ELISA: Enzyme-linked immunosorbent assay; FBS: Fetal bovine serum; FSG: Female salivary gland extract; FSGR: Female salivary gland from ticks fed on resistant Nelores; FSGS: Female salivary gland from ticks fed on susceptible Holsteins; IgG: Immunoglobulin G; IgGBPs: Immunoglobulin G-binding proteins; LC-MS: Liquid chromatography - mass spectrometry; MSG: Male salivary gland extract; MSGR: Male salivary gland from tick fed on resistant Nelores; MSGS: Male salivary gland from tick fed on susceptible Holsteins; PBS: Phosphate buffered saline; PVDF: Polyvinylidene fluoride; TBS-T: TRIS buffered saline-tween 20; TMB: 3,3',5,5'-tetramethylbenzidine; UFL: Extract of unfed larvae; UFLR: Extract of unfed larvae originated from female ticks fed on resistant Nelores; UFLS: Extract of unfed larvae originates from female ticks fed on susceptible Holsteins

\section{Acknowledgements}

The authors thank Dr. João S. Silva and Ana Patricia Yatsuda Natsui for generous and continuing support of this work, which was partially performed in their laboratories.

\section{Funding}

This study was supported by a grant to IKFMS from the Conselho Nacional de Desenvolvimento Científico e Tecnológico (CNPq grant number 559603/ 2009-6) and from the Fundação de Amparo à Pesquisa do Estado de São Paulo (FAPESP grant number 2009/53645-3). GRG. was supported by scholarships from the Fundação de Amparo à Pesquisa do Estado de São Paulo (FAPESP, fellowships: 2007/51532-1, 2009/51212-2 and 2013/00382-0). SRM was supported by scholarships from FAPESP (2006/54041-6, 2007/ 59357-4, 2012/15464-0 and 2012/04087-0). Because JMCR, JGV and JMA are government employees and this is a government work, the work is in the public domain in the United States. Notwithstanding any other agreements, the NIH reserves the right to provide the work to PubMedCentral for display and use by the public, and PubMedCentral may tag or modify the work consistent with its customary practices. Rights can be established outside of the United States subject to a government use license.

\section{Availability of data and materials}

Additional file 2 contains the identification of all spots recovered and sequenced from immunoblotting analyses using two-dimensional gel electrophoresis. The mass spectrometry proteomics data have been deposited to the ProteomeXchange Consortium via the PRIDE [83] partner repository with the dataset identifier PXD005773 [http://proteomecentral.proteo mexchange.org/cgi/GetDataset].

\section{Authors' contributions}

IKFMS designed the experiments; GRG, KN, APYN, SRM, LGG and AAMM performed the experiments; GRG, KN, JMCR, BRF, and IKFMS analyzed the 
results; JMCR and FNJK furnished essential materials; GRG, SRM and IKFMS wrote the manuscript. All authors read and approved the final manuscript.

\section{Competing interests}

The authors declare that they have no competing interests.

\section{Consent for publication}

Not applicable.

\section{Ethics approval}

This study is in accordance with the Ethical Principles in Animal Research adopted by Brazilian College of Animal Experimentation (protocol number 055/2007) and was approved by the Ribeirão Preto School of Medicine of the University of São Paulo in 05/28/2007.

\section{Publisher's Note}

Springer Nature remains neutral with regard to jurisdictional claims in published maps and institutional affiliations.

\begin{abstract}
Author details
'Department of Biochemistry and Immunology, Ribeirão Preto School of Medicine, University of São Paulo, Ribeirão Preto, São Paulo, Brazil. ${ }^{2}$ Center for the Study of Biological Complexity, Virginia Commonwealth University, Richmond, VA, USA. ${ }^{3}$ Laboratory of Malaria and Vector Research, National Institute of Allergy and Infectious Diseases, National Institutes of Health, Rockville, MD, USA. ${ }^{4}$ Department of Basic Sciences, School of Animal Science and Food Technology, University of São Paulo, Pirassununga, São Paulo, Brazil. ${ }^{5}$ Department of Maternal-Child Nursing and Public Health, Ribeirão Preto School of Nursing, USP, Ribeirão Preto, SP, Brazil. ${ }^{6}$ Department of Infectious Diseases and Immunology, Faculty of Veterinary Medicine, Utrecht University, Utrecht, The Netherlands.
\end{abstract}

\section{Received: 15 October 2016 Accepted: 6 March 2017 Published online: 14 March 2017}

\section{References}

1. Steelman CD. Effects of external and internal arthropod parasites on domestic livestock production. Annu Rev Entomol. 1976;21:155-78.

2. Jonsson NN, Davis R, De Witt M. An estimate of the economic effects of cattle tick (Boophilus microplus) infestation on Queensland dairy farms. Aust Vet J. 2001;79:826-31.

3. Jongejan F, Uilenberg G. The global importance of ticks. Parasitology. 2004; 129(Suppl):S3-S14.

4. Grisi L, Leite RC, Martins JR de S, Barros ATM de, Andreotti R, Cançado PHD, et al. Reassessment of the potential economic impact of cattle parasites in Brazil. Rev Bras Parasitol Veterinária. 2014;23:150-6.

5. Dalton JP, Mulcahy G. Parasite vaccines - a reality? Vet Parasitol. 2001;98:149-67.

6. Pruett $\mathrm{JH}$. Identification and purification of a $16-\mathrm{kDa}$ allergen from Psoroptes ovis (Acarina: Psoroptidae). J Med Entomol. 1999;36:544-50.

7. Utech KGW. Resistance to Boophilus microplus (Canestrini) in different breeds of cattle. Aust J Agric Res. 1978;29:885-95.

8. Wambura PN, Gwakisa PS, Silayo RS, Rugaimukamu EA. Breed-associated resistance to tick infestation in Bos indicus and their crosses with Bos taurus. Vet Parasitol. 1998;77:63-70.

9. Bradley DG, Loftus RT, Cunningham P, MacHugh DE. Genetics and domestic cattle origins. Evol Anthropol Issues News Rev. 1998;6:79-86.

10. MacHugh DE, Shriver MD, Loftus RT, Cunningham P, Bradley DG. Microsatellite DNA variation and the evolution, domestication and phylogeography of taurine and zebu cattle (Bos taurus and Bos indicus). Genetics. 1997;146:1071-86.

11. Estrada-Pena A, Bouattour A, Camicas JL, Guglielmone A, Horak I, Jongejan $F$, et al. The known distribution and ecological preferences of the tick subgenus Boophilus (Acari: Ixodidae) in Africa and Latin America. Exp Appl Acarol. 2006;38:219-35.

12. Mattioli RC, Cassama M. Comparison of characteristics of life cycle in female ticks collected on N'Dama and zebu cattle. Trop Anim Health Prod. 1995;27:150-4

13. Mattioli RC, Pandey VS, Murray M, Fitzpatrick JL. Immunogenetic influences on tick resistance in African cattle with particular reference to trypanotolerant N'Dama (Bos taurus) and trypanosusceptible Gobra zebu (Bos indicus) cattle. Acta Trop. 2000;75:263-77.
14. Seifert GW. Ectoparasitic and endoparasitic effects on growth rates of zebu crossbred and British cattle in field. Aust J Agric Res. 1971;22:839-50.

15. Utech KB, Wharton RH. Breeding for resistance to Boophilus microplus in Australian Illawarra Shorthorn and Brahman $\times$ Australian Illawarra Shorthorn cattle. Aust Vet J. 1982;58:41-6.

16. Biegelmeyer P, Nizoli LQ, da Silva SS, dos Santos TRB, Dionello NJL, GuliasGomes CC, et al. Bovine genetic resistance effects on biological traits of Rhipicephalus (Boophilus) microplus. Vet Parasitol. 2015;208:231-7.

17. Francischetti IMB, Sa-Nunes A, Mans BJ, Santos IM, Ribeiro JMC. The role of saliva in tick feeding. Front Biosci Landmark Ed. 2009;14:2051-88.

18. Kazimírová M, Štibrániová I. Tick salivary compounds: their role in modulation of host defences and pathogen transmission. Front Cell Infect Microbiol. 2013;3:43.

19. Bowman AS, Coons LB, Needham GR, Sauer JR. Tick saliva: recent advances and implications for vector competence. Med Vet Entomol. 1997;11:277-85.

20. Leal BF, Seixas A, Mattos RT, Coutinho ML, Masuda A, da Silva VI, et al. Tissue expression and the host's immunological recognition of a Rhipicephalus microplus paramyosin. Vet Parasitol. 2013:197:304-11.

21. Constantinoiu CC, Jackson LA, Jorgensen WK, Lew-Tabor AE, Piper EK, Mayer DG, et al. Local immune response against larvae of Rhipicephalus (Boophilus) microplus in Bos taurus indicus and Bos taurus taurus cattle. Int J Parasitol. 2010:40:865-75.

22. Ramírez Rodríguez PB, Rosario Cruz R, Domínguez García Dl, Hernández Gutiérrez R, Lagunes Quintanilla RE, Ortuño Sahagún D, et al. Identification of immunogenic proteins from ovarian tissue and recognized in larval extracts of Rhipicephalus (Boophilus) microplus, through an immunoproteomic approach. Exp Parasitol. 2016;170:227-35.

23. Golub ES, Weigle WO. Studies on the induction of immunologic unresponsiveness. I. Effects of endotoxin and phytochemagglutinin. J Immunol Baltim Md 1950. 1967;98:1241-7.

24. Dresser DW. Specific inhibition of antibody production. II Paralysis induced in adult mice by small quantities of protein antigen Immunology. 1962:5:378-88.

25. Kashino SS, Resende J, Sacco AM, Rocha C, Proenca L, Carvalho WA, et al. Boophilus microplus: the pattern of bovine immunoglobulin isotype responses to high and low tick infestations. Exp Parasitol. 2005;1 10:12-21.

26. Cruz APR, Silva SS, Mattos RT, Da Silva VI, Masuda A, Ferreira C aS. Comparative lgG recognition of tick extracts by sera of experimentally infested bovines. Vet Parasitol. 2008:158:152-8.

27. Piper EK, Jonsson NN, Gondro C, Lew-Tabor AE, Moolhuijzen P, Vance ME, et al. Immunological profiles of Bos taurus and Bos indicus cattle infested with the cattle tick, Rhipicephalus (Boophilus) microplus. Clin Vaccine Immunol. 2009;16:1074-86.

28. Maruyama SR, Anatriello E, Anderson JM, Ribeiro JM, Brandão LG, Valenzuela $J G$, et al. The expression of genes coding for distinct types of glycine-rich proteins varies according to the biology of three metastriate ticks, Rhipicephalus (Boophilus) microplus. Rhipicephalus sanguineus and Amblyomma cajennense BMC Genomics. 2010;11:363.

29. Maruyama SR, Castro-Jorge LA, Ribeiro JMC, Gardinassi LG, Garcia GR, Brandão LG, et al. Characterisation of divergent flavivirus NS3 and NS5 protein sequences detected in Rhipicephalus microplus ticks from Brazil. Mem Inst Oswaldo Cruz. 2014;109:38-50.

30. Franzin AM, Maruyama SR, Garcia GR, Oliveira RP, Ribeiro JMC, Bishop R, et al. Immune and biochemical responses in skin differ between bovine hosts genetically susceptible and resistant to the cattle tick Rhipicephalus microplus. Parasit Vectors. 2017:10:51.

31. Kooyman FN, Van Kooten PJ, Huntley JF, MacKellar A, Cornelissen AW, Schallig HD. Production of a monoclonal antibody specific for ovine immunoglobulin $\mathrm{E}$ and its application to monitor serum lgE responses to Haemonchus contortus infection. Parasitology. 1997;114(Pt 4):395-406.

32. Carvalho WA, lanella P, Arnoldi FG, Caetano AR, Maruyama SR, Ferreira BR, et al. Haplotypes of the bovine lgG2 heavy gamma chain in tick-resistant and tick-susceptible breeds of cattle. Immunogenetics. 2011;63:319-24.

33. Biozzi G, Asofsky R, Lieberman R, Stiffel C, Mouton D, Benacerraf B. Serum concentrations and allotypes of immunoglobulins in two lines of mice genetically selected for "high" or "low" antibody synthesis. J Exp Med. 1970;132:752-64

34. Natsuume-Sakai S, Motonishi K, Migita S. Quantitative estimations of five classes of immunoglobulin in inbred mouse strains. Immunology. 1977;32:861-6.

35. Norman LM, Hohenboken WD, Kelley KW. Genetic differences in concentration of immunoglobulins $\mathrm{G} 1$ and $\mathrm{M}$ in serum and colostrum of cows and in serum of neonatal calves. J Anim Sci. 1981;53:1465-72. 
36. Allansmith M, McClellan B, Butterworth $M$. The influence of heredity and environment on human immunoglobulin levels. J Immunol Baltim Md 1950. 1969;102:1504-10

37. Rechav Y. Resistance of Brahman and Hereford cattle to African ticks with reference to serum gamma globulin levels and blood composition. Exp Appl Acarol. 1987:3:219-32.

38. Siqueira M, Esteves MB, Ibanez OM, Ferreira VA, Sant'Anna OA, Reis MH, et al. Nonspecific genetic regulation of antibody responsiveness in the mouse. Eur J Immunol. 1977;7:195-203.

39. Vaz Júnior I da S, Martinez RH, Oliveira A, Heck A, Logullo C, Gonzales JC, et al. Functional bovine immunoglobulins in Boophilus microplus hemolymph. Vet Parasitol. 1996;62:155-60.

40. Wang H, Paesen GC, Nuttall PA, Barbour AG. Male ticks help their mates to feed. Nature. 1998;391:753-4.

41. Carvalho WA, Bechara GH, Moré DD, Ferreira BR, da Silva JS, de Miranda Santos IKF. Rhipicephalus (Boophilus) microplus: distinct acute phase proteins vary during infestations according to the genetic composition of the bovine hosts, Bos taurus and Bos indicus. Exp Parasitol. 2008;118:587-91.

42. Tolleson DR, Teel PD, Stuth JW, Strey OF, Welsh TH, Carstens GE, et al. Effects of a lone star tick (Amblyomma americanum) burden on performance and metabolic indicators in growing beef steers. Vet Parasitol. 2010;173:99-106.

43. Burdick NC, Banta JP, Neuendorff DA, White JC, Vann RC, Laurenz JC, et al. Interrelationships among growth, endocrine, immune, and temperament variables in neonatal Brahman calves. J Anim Sci. 2009;87:3202-10.

44. Brambell FW, Hemmings WA, Morris IG. A Theoretical model of gammaglobulin catabolism. Nature. 1964;203:1352-4.

45. Humphrey $\mathrm{JH}$, Fahey $\mathrm{J}$. The metabolism of normal plasma proteins and gamma-myeloma protein in mice bearing plasma-cell tumors. J Clin Invest. 1961:40:1696-705.

46. Cauza K, Hinterhuber G, Dingelmaier-Hovorka R, Brugger K, Klosner G, Horvat $\mathrm{R}$, et al. Expression of FCRn, the MHC class I-related receptor for lgG, in human keratinocytes. J Invest Dermatol. 2005:124:132-9.

47. Cianga P, Cianga C, Plamadeala P, Branisteanu D, Carasevici E. The neonatal Fc receptor ( $F C R n)$ expression in the human skin. Virchows Arch Int J Pathol. 2007;451:859-60.

48. Van Bilsen K, van Hagen PM, Bastiaans J, van Meurs JC, Missotten T, Kuijpers $\mathrm{RW}$, et al. The neonatal Fc receptor is expressed by human retinal pigment epithelial cells and is downregulated by tumour necrosis factor-alpha. $\mathrm{Br} J$ Ophthalmol. 2011;95:864-8.

49. Liu X, Ye L, Bai Y, Mojidi H, Simister NE, Zhu X. Activation of the JAK/STAT-1 signaling pathway by IFN-gamma can down-regulate functional expression of the MHC class I-related neonatal Fc receptor for lgG. J Immunol Baltim Md 1950. 2008:181:449-63.

50. Lu J, Marjon KD, Mold C, Du Clos TW, Sun PD. Pentraxins and FC receptors. Immunol Rev. 2012;250:230-8.

51. Allen JR, Khalil HM, Graham JE. The location of tick salivary antigens, complement and immunoglobulin in the skin of guinea-pigs infested with Dermacentor andersoni larvae. Immunology. 1979;38:467-72.

52. Meiler F, Zumkehr J, Klunker S, Rückert B, Akdis CA, Akdis M. In vivo switch to IL-10-secreting T regulatory cells in high dose allergen exposure. J Exp Med. 2008;205:2887-98.

53. Ferreira BR, Silva JS. Successive tick infestations selectively promote a T-helper 2 cytokine profile in mice. Immunology. 1999;96:434-9.

54. Menten-Dedoyart C, Couvreur B, Thellin O, Drion PV, Herry M, Jolois O, et al. Influence of the Ixodes ricinus tick blood-feeding on the antigen-specific antibody response in vivo. Vaccine. 2008;26:6956-64.

55. Menten-Dedoyart C, Couvreur B, Jolois O, Van Lerberghe PB, Duwez L, Drion $P$, et al. Kinetic study of the antibody response during the blood meal of Ixodes ricinus: implication on plasma cell maturation in vivo and for antiIxodes vaccination. Vaccine. 2011;29:2044-50

56. Tirloni L, Reck J, Terra RMS, Martins JR, Mulenga A, Sherman NE, et al. Proteomic analysis of cattle tick Rhipicephalus (Boophilus) microplus saliva: a comparison between partially and fully engorged females PLoS One. 2014;9:e94831.

57. Tirloni L, Islam MS, Kim TK, Diedrich JK, Yates JR, Pinto AFM, et al. Saliva from nymph and adult females of Haemaphysalis longicornis: a proteomic study. Parasit Vectors. 2015;8:338

58. Oliveira CJ, Anatriello E, de Miranda-Santos IK, Francischetti IM, Sá-Nunes A Ferreira BR, et al. Proteome of Rhipicephalus sanguineus tick saliva induced by the secretagogues pilocarpine and dopamine. Ticks Tick-Borne Dis. 2013:4:469-77.
59. Díaz-Martín V, Manzano-Román R, Valero L, Oleaga A, Encinas-Grandes A, Pérez-Sánchez R. An insight into the proteome of the saliva of the argasid tick Ornithodoros moubata reveals important differences in saliva protein composition between the sexes. J Proteomics. 2013;80:216-35.

60. Ribeiro JM, Anderson JM, Manoukis NC, Meng Z, Francischetti IM. A further insight into the sialome of the tropical bont tick Amblyomma variegatum. BMC Genomics. 2011;12:136.

61. Whitten MMA, Tew IF, Lee BL, Ratcliffe NA. A novel role for an insect apolipoprotein (apolipophorin III) in beta-1,3-glucan pattern recognition and cellular encapsulation reactions. J Immunol Baltim Md 1950. 2004; 172:2177-85.

62. Johannessen BR, Skov LK, Kastrup JS, Kristensen O, Bolwig C, Larsen JN, et al Structure of the house dust mite allergen Der $\mathrm{f} 2$ : implications for function and molecular basis of IgE cross-reactivity. FEBS Lett. 2005;579:1208-12.

63. Karim S, Singh P, Ribeiro JMC. A deep insight into the sialotranscriptome of the Gulf Coast tick Amblyomma maculatum. PLoS One. 2011;6(12):e28525.

64. Anatriello E, Ribeiro JMC, de Miranda-Santos IKF, Brandão LG, Anderson JM, Valenzuela JG, et al. An insight into the sialotranscriptome of the brown dog tick Rhipicephalus sanguineus. BMC Genomics. 2010;11:450.

65. Radulović ŽM, Kim TK, Porter LM, Sze S-H, Lewis L, Mulenga A. A 24-48 h fed Amblyomma americanum tick saliva immuno-proteome. BMC Genomics. 2014;15:518

66. Willadsen P, Wood GM, Riding GA. The relation between skin histamine concentration, histamine sensitivity, and the resistance of cattle to the tick Boophilus microplus. Z Für Parasitenkd. 1979;59:87-93.

67. Liao M, Boldbaatar D, Gong H, Huang P, Umemiya R, Harnnoi T, et al. Functional analysis of protein disulfide isomerases in blood-feeding, viability and oocyte development in Haemaphysalis longicornis ticks. Insect Biochem Mol Biol. 2008;38:285-95

68. Rodriguez-Valle M, Vance M, Moolhuijzen PM, Tao X, Lew-Tabor AE. Differential recognition by tick-resistant cattle of the recombinantly expressed Rhipicephalus microplus serine protease inhibitor-3 (RMS-3). Ticks Tick-Borne Dis. 2012;3:159-69.

69. Boldbaatar D, Umemiya-Shirafuji R, Liao M, Tanaka T, Xuan X, Fujisaki K. Multiple vitellogenins from the Haemaphysalis longicornis tick are crucial for ovarian development. J Insect Physiol. 2010;56:1587-98.

70. Kotsyfakis M, Anderson JM, Andersen JF, Calvo E, Francischetti IM, Mather TN et al. Cutting edge: Immunity against a "silent" salivary antigen of the Lyme vector Ixodes scapularis impairs its ability to feed. J Immunol. 2008;181:5209-12.

71. Kawamoto S, Yalcindag A, Laouini D, Brodeur S, Bryce P, Lu B, et al. The anaphylatoxin $\mathrm{C} 3$ a downregulates the Th2 response to epicutaneously introduced antigen. J Clin Invest. 2004;114:399-407.

72. Willadsen P, Riding GA. On the biological role of a proteolytic-enzyme inhibitor from the ectoparasitic tick Boophilus microplus. Biochem J. 1980; 189:295-303.

73. Ribeiro JM. Ixodes dammini: salivary anti-complement activity. Exp Parasitol. 1987;64:347-53.

74. Ashton-Rickardt PG. An emerging role for serine protease inhibitors in T lymphocyte immunity and beyond. Immunol Lett. 2013;152:65-76.

75. Rodriguez-Valle M, Xu T, Kurscheid S, Lew-Tabor AE. Rhipicephalus microplus serine protease inhibitor family: annotation, expression and functional characterisation assessment. Parasit Vectors. 2015:8:7.

76. Tirloni L, Seixas A, Mulenga A, Vaz I da S, Termignoni C. A family of serine protease inhibitors (serpins) in the cattle tick Rhipicephalus (Boophilus) microplus. Exp Parasitol. 2014;137:25-34

77. Tirloni L, Kim TK, Coutinho ML, Ali A, Seixas A, Termignoni C, et al. The putative role of Rhipicephalus microplus salivary serpins in the tick-host relationship. Insect Biochem Mol Biol. 2016;71:12-28.

78. Willadsen P, McKenna RV. Binding of antigens to tissues: the example of Boophilus microplus and bovine skin. Int J Parasitol. 1983;13:593-8.

79. Trager W. Acquired immunity to ticks. J Parasitol. 1939;25:57-81.

80. Roberts JA, Kerr JD. Boophilus microplus: passive transfer of resistance in cattle. J Parasitol. 1976;62:485-8.

81. Lleo A, Invernizzi P, Gao B, Podda M, Gershwin ME. Definition of human autoimmunity-autoantibodies versus autoimmune disease. Autoimmun Rev. 2010;9:A259-66.

82. Uhlír J, Grubhoffer L, Borský l, Dusbábek F. Antigens and glycoproteins of larvae, nymphs and adults of the tick Ixodes ricinus. Med Vet Entomol. 1994;8:141-50.

83. Vizcaíno JA, Csordas A, Del-Toro N, Dianes JA, Griss J, Lavidas I, et al. 2016 update of the PRIDE database and its related tools. Nucleic Acids Res. 2016; 44:11033. 